\title{
Defining the genetic profile of endometriosis (Review)
}

\author{
LOUKIA VASSILOPOULOU ${ }^{1}$, MICHAIL MATALLIOTAKIS ${ }^{2,3}$, MARIA I. ZERVOU ${ }^{4}$, \\ CHAROULA MATALLIOTAKI ${ }^{2,3}$, KONSTANTINOS KRITHINAKIS ${ }^{5}$, IOANNIS MATALLIOTAKIS ${ }^{3}$, \\ DEMETRIOS A. SPANDIDOS ${ }^{6}$ and GEORGE N. GOULIELMOS ${ }^{4}$
}

\author{
${ }^{1}$ Laboratory of Forensic Sciences and Toxicology, School of Medicine, University of Crete, Heraklion 71003; \\ ${ }^{2}$ Third Department of Obstetrics and Gynecology, Aristotle University of Thessaloniki, Thessaloniki 54124; \\ ${ }^{3}$ Department of Obstetrics and Gynecology, Venizeleio and Pananio General Hospital of Heraklion, Heraklion 71409; \\ ${ }^{4}$ Section of Molecular Pathology and Human Genetics, Department of Internal Medicine, School of Medicine, \\ University of Crete, Heraklion 71003; ${ }^{5}$ Department of Obstetrics and Gynecology, University Hospital of Heraklion, \\ Heraklion 71500; ${ }^{6}$ Laboratory of Clinical Virology, School of Medicine, University of Crete, Heraklion 71003, Greece
}

Received January 21, 2019; Accepted March 1, 2019

DOI: $10.3892 /$ etm.2019.7346

\begin{abstract}
Endometriosis is a pathological condition which has been extensively studied, since its pathophysiology stems from a broad spectrum of environmental influences and genetic factors. Familial studies aim at defining inheritance trends, while linkage analysis studies focus on the identification of genetic sites related to endometriosis susceptibility. Genetic association studies take into account candidate genes and single nucleotide polymorphisms, and hence target at unraveling the association between disease severity and genetic variation. The common goal of various types of studies is, through genetic mapping methods, the timely identification of therapeutic strategies for disease symptoms, including pelvic pain and infertility, as well as efficient counselling. While genome-wide association studies (GWAS) play a primary role in depicting genetic contributions to disease development, they entail a certain bias as regards the case-control nature of their design and the reproducibility of the results. Nevertheless, genetic-oriented studies and the implementation of the results through clinical tests, hold a considerable advantage in proper disease management. In this review article, we present information about gene-gene and gene-environment interactions involved in endometriosis and discuss the effectiveness of GWAS in identitying novel potential therapeutic targets in an attempt to develop novel therapeutic strategies for a better management and treatment of patients with endometriosis.
\end{abstract}

Correspondence to: Dr George N. Goulielmos, Section of Molecular Pathology and Human Genetics, Department of Internal Medicine, School of Medicine, University of Crete, Voutes, Heraklion 71003, Greece

E-mail: goulielmos@med.uoc.gr

Key words: endometriosis, gene polymorphisms, genomewide association studies, linkage analysis, single nucleotide polymorphisms, candidate genes, genetic association studies

\section{Contents}

1. Introduction

2. Family aggregates and twin studies

3. Linkage analysis studies

4. Genetic association studies

5. Genome-wide association studies

6. Conclusions and future perspectives

\section{Introduction}

Endometriosis is an estrogen-dependent disease, defined by the development of endometrial tissue in ectopic sites (1). Chronic pelvic pain, dysmenorrhea and impaired fertility represent the main symptoms, with laparoscopy and biopsy still being the gold-standard for diagnosis (2). Endometriosis-induced infertility predominantly occurs due to ovarian dysfunction, as a result of mechanisms interfering with folicullogenesis and endometrial receptivity, and represents the main reason women of reproductive age resort to methods of assisted reproduction, such as in vitro fertilization (IVF) and intracytoplasmic sperm injection (ICSI) (3). Thus, endometriosis has been an issue of particular interest for clinical doctors and researchers, since it hinders fecundity in approximately one tenth of women elapsing their reproductive years.

Multiple theories have been put forward regarding the operative events provoking the disease, with the hypothesis of retrograde menstruation dispelling functional endometrial cells into the peritoneal cavity along the salpinges, being the oldest and most prevalent (4). Previously, whole-exome sequencing, in search of somatic mutations in the endometrial tissues of 16 cases, demonstrated that the majority of genes involved in cell adhesions, junctions and chromatin-remodeling complexes were mutated in both eutopic and ectopic tissues (5). Additional suggestions regarding disease pathophysiology pertain to steroid function, an altered peritoneal biochemical and cellular environment (6), oxidative stress and induced inflammation, as well as defective immune surveillance and augmented angiogenesis (7). 
Indeed, its etiology and pathogenesis exhibit complexity, as both genetic influences and environmental contributors seem to formulate the disease phenotype (8). Since the multifactorial nature of endometriosis involves the participation of immune mechanisms, angiogenetic processes and biochemical alterations, it can be deduced that genetic factors, as well as epigenetic modifications act together for disease manifestation. The heritability pattern of endometriosis was first proposed by Goodall in 1943, through his references on 5 family history cases (9). Ever since, further familial studies have been performed.

\section{Family aggregates and twin studies}

Familial aggregation studies generally pertain to the amassing of specific traits encountered in a given family, which cannot be attributed to coincidental events. These studies are utilized for the detection of genetic factors that contribute to the manifestation of a studied disease (10), designed by gathering representative subjects, named as probands, and recording an extensive family history.

In previous a case-control study, including a British population sample of 64 women with a visual diagnosis of endometriosis, $9.4 \%$ of patients had a first-degree relative with endometriosis (11), while in another retrospective cohort study of 80 patients, endometriosis was detected in $5.9 \%$ of the patients' first-degree relatives, underlining the familial tendency of the disease (12). In accordance with this, another study reported that patients' sisters presented with an $8.8 \%$ percentage of endometriosis, with the relative risk being equal to 5.7 , in a total of 339 women with the disorder (13). Upon further expanding this to further degrees of kinship, disease prevalence was previously examined in relatives of a group of 101 patients with diagnosed endometriosis; 7 first-, 3 secondand 2 third-degree relatives were affected, further verifying the hereditary character of the disorder (14). Moreover, the heritability of endometriosis has been put under investigation in multitudinous Utah families. For this purpose, three-generation family histories were retrieved from 117 probands; not only first-degree relatives, but also second-degree relatives were reportedly diagnosed with the disease (15). In a previous population-based study, the risk ratio for female siblings equaled to 5.20 , as opposed to 1.56 for cousins, while the average kinship coefficient for female patients was notably elevated in comparison to the one estimated for 1,000 sets of 750 matched controls (16). In another study, the assessment of 800 medical reports, including 400 surgical patients, suggested that the total risk for endometriosis of first-degree patients' relatives increased up to $10.2 \%$, with the same percentage being only $0.7 \%$ for the controls (17). Complementary to the above-mentioned results, an investigation of 526 medical records at the Yale Haven Hospital for the sexennial period between 1996-2002, revealed an association of familial risk for ovarian, colon and prostate cancer in women with endometriosis, both for patients and for their first- and second- degree relatives (18). Endometriosis can, in fact, manifest in species, whose reproductive function involves menstruation. Familial aggregation has been studied in a species belonging to the primates order, where it has been displayed to be elevated, as well as the risk of recurrence among members of the same family, indicating the inheritance pattern of endometriosis in other species, apart from humans (19).
Twin studies are utilized for the evaluation of genetics participation in contrast to the environmental influences regarding a given feature. Limitations and assumptions are an intrinsic trait of these types of studies; their results, however, have been shown to be ascertained by molecular genetic studies (20). A previous monozygotic and dizygotic twin pair study entailed 215 twins with self-reported endometriosis, with the data varying in relevance to medical reports, indicating that this deviation may be attributed to further genetic impingement. The ratio between monozygotic and dizygotic twins was $2: 1$, with the overall available information suggesting that genetic contribution bears an important association with disease manifestation (21). In another study, in 16 monozygotic pairs, 9 were in congruence with an advanced endometriosis stage, while in 5 pairs out of the 7 discordant pairs, one twin had mild disease, while the other had either advanced or deep infiltrating disease. Furthermore, women in the two discordant monozygotic twins presented with infertility (22). In a cohort study comprised of 3,595 monozygotic and 3,601 dizygotic female twin pairs, concordance among probands was 0.21 and 0.1 for monozygotic and dizygotic twins, respectively, while in monozugotes the tetrachoric correlation was elevated as well (23). It can thus be deduced that genetic influences in this sample accounted for almost half of the total contribution to the disease phenotype, with environmental factors seemingly playing an equal role.

\section{Linkage analysis studies}

The aim of linkage analysis studies is the mathematical interpretation of pedigree data for the investigation of allelic cosegregation at a suspect genetic locus (24). This correlation does not imply a random event, rather their adjacent location on chromosomes, which enables their co-inheritance (25). Linkage analysis studies were widely used over the past 50 years of the previous century, conceding their place to genome-wide association studies (GWAS) (26). Linkage studies contribute to the investigation of genomic regions that are likely to include genetic polymorphisms related to disease risk (27). However, an intrinsic drawback is that the exact accountable gene or polymorphism cannot be singled out, since elongated genomic regions are given prominence to. In an attempt to mitigate this problem, single nucleotide polymorphism (SNP) association studies have been put into implementation.

The Oxford Endometriosis Gene (OXEGENE) study, an international undertaking, aimed, via the technique of linkage analysis, at the identification of genetic loci associated with susceptibility to endometriosis (28). For this purpose, the International Endogene Study, a conflation of the OXEGENE and the Genes Behind Endometriosis Australian study, recruited $>1,000$ families, whose participants belonged mainly to affected sibling-pair groups, for a positional cloning strategy (29). Three years later, in a similar linkage study of 1,176 families, segments of important linkage were detected on chromosome 10q26 and suggestively $20 \mathrm{p} 13$, along with several minor potential loci (30). Aiming at positional cloning approach, this combined study included at least 2 affected members with surgical diagnosis of the disease. The sibling recurrence ratio was calculated as $\geq 1.3$ ( $\left.\lambda_{\mathrm{s}}=1.3\right)$ in comparison to the general population. In an effort to determine whether this particular accumulation of cases among families with numerous members affected 
can be justified according to (near-) the Mendelian autosomal inheritance principle, Zondervan et al in 2007 (31) came across the conclusion that one or more high-penetrance susceptibility loci on chromosome 7p13-15 exist for endometriosis, following the afore-mentioned pattern of inheritance. Genes included in regions highlighted by linkage analysis, should subsequently be examined as potential candidates bearing mutations responsible for disease development. Since no single gene is solely linked with a disease, localizing respective genes proves to be a rather demanding task. In another study investigating 3,223 cases of endometriosis for 11,948 SNPs located on chromosome 10 (on chromosome 10q26 in a study of 1,176 families), it was revealed that through linkage analysis method, a relation existed between endometriosis on chromosome 10 (32).

\section{Genetic association studies}

Genetic association studies are widely used for the detection of candidate genes and genomic regions that contribute to formation of disease phenotype, by examining the relation between disease status and genetic variation. Given the suggested pathophysiology mechanisms of endometriosis, study subjects revolve around cellular proliferation/differentiation/migration, tumor suppression/growth, apoptosis, angiogenesis and inflammation-related genes (Table I), particularly aiming at tracing SNPs, microsatellite markers, insertion/deletion variable tandem repeats and copy-number variants (33).

\section{Cellular cycle-, proliferation- and apoptosis-related loci}

i) DNA mismatch repair. The Arg399Gln polymorphism in the $\mathrm{X}$-ray repair cross-complementing group 1 (XRCC1) gene, one of the DNA repair pathway genes, has been suggested to be associated with the risk of developing endometriosis, particularly in Asian populations. Specifically, the A allele has been shown to consist of a preventive factor for the disease (34), with the AA genotype exhibits a significant association with a reduced risk of endometriosis if compared to GG. The XRCC1 Arg399Gln polymorphism is not only associated with an increased disease susceptibility (as regards the ' $G G$ ' genotype), but may also potentially serve as a biomarker (35). As regards XRCC4, codon $247^{*} \mathrm{~A}$ - and promoter $1394 * \mathrm{~T}$-related genotypes and alleles might as well be associated with endometriosis (36). hMLHI is another component of the DNA mismatch repair system genes that corrects errors in DNA replication for the achievement of genomic integrity. The suppressed expression of $h M L H 1$ can possibly lead to the deterioration of the endometriosis progression stage (37).

ii) Proliferation/differentiation. Modifications have been identified in endometriotic lesions in the homeobox (HOX) genes cluster, which encode for fetal development. The HOXA10 gene participates in the embryogenesis of the uterus and embryo implantation through the regulation of downstream genes. $H O X-A$ and $H O X-B$ incur downregulation, while $H O X-C$ upregulation (38). HOXA10 and HOXA11, known to be upregulated during implantation, reportedly exhibit reduced product levels during the same period in women with endometriosis (39). It seems that patients do not display the expected mid-luteal rise of $H O X A 10$ expression, hence endometriosis-induced infertility can be partially explained (40). Empty spiracles homeobox 2(EMX2) is a transcription factor necessary for female
Müllerian duct differentiation and development, also being a known direct target of $H O X A 10$ in the reproductive tract. EMX2 regulates human teneurin transmembrane protein 1 (TENMI) in a direct manner, the expression of the latter being associated with embryonic pattern formation and morphogenesis. Thus, it has been proposed that alterations in HOXA10, EMX2 and TENM1 expression levels may act in infertile women with a Müllerian duct anomaly to cause a partially septate uterus (41). In a study of 45 affected women, HOXA11-AS1 IncRNA was shown to participate in the development of peritoneal endometriosis. In detail, the HOXA11-AS1 1ncRNA and HOXA9, HOXA10, HOXA11 and HOXA13 mRNAs were expressed at notably decreased levels in the eutopic than in the ectopic endometrium in women with peritoneal endometriosis. Indeed, patients with peritoneal endometriosis, compared to the healthy control samples, demonstrated a noticeably reduced expression of HOXA10 and HOXA11 in the eutopic endometrium, while the IncRNA (HOXA11-AS1), HOXA9 and HOXA13 levels did not present a considerable difference between the two patient groups (42). The expression of not only HOXA11, but also of leukemia inhibitory factor $(L I F)$ and basic transcriptional element binding protein1 (BTEB1) in the endometrium during the mid-luteal phase, was shown to be suppressed in women with endometriosis compared to healthy women (43).

The $p 27$ gene is responsible for maintaining cellular cycle and differentiation; the single nucleotide polymorphism in codon 109 (V109G) has been shown to be related to an increased risk of developing endometriosis (44). The secretory phospholipase A2 group IIa (PLA2G2A) gene induces cell proliferation; its polymorphism $763 \mathrm{C}>\mathrm{G}$ has been linked with endometriosis in an Iranian women population (45). Moreover, an association has been observed between polymorphisms in the laminin subunit alpha 1 (LAMA) and kazrin, periplakin interacting protein $(K A Z N)$ genes and endometriosis. The $K A Z N$ is a gene encoding a protein for cell adhesion; the $G$ variant of the rs10928050 SNP of this gene seems to be encountered more frequently in patients with endometriosis than in healthy controls. The LAMA5 is a gene involved in various cellular processes, including differentiation, adhesion, migration and angiogenesis. An important association has been accentuated among the LAMA5 rs2427284 SNP and endometriosis stages III and IV (46).

iii) Apoptosis. The eutopic endometrium of patients seems to hold a unique molecular signature, since in 91 out of 579 genes involved in cell apoptosis modulation and decidualization, a significant aberration has been noted between cases and controls (47). A notable aberration seems to exist in the Fas cell surface death receptor $(F A S)$ gene rs13416436 and rs2037815 SNPs, among patients and controls of Brazilian origin; the haplotype containing the rs $3740286 \mathrm{~A}$ and $\mathrm{rs} 4064 \mathrm{G}$ alleles in the $F A S$ gene hold statistical significance (48). Calpains are also involved in the regulation of apoptosis; indeed, calpain5 acts as a target of HOXA10 transcriptional regulation in endometrial cells, indicating that a low $H O X A 10$ expression affects calpain5 expression accordingly (49). The KRAS proto-oncogene, GTPase (KRAS), sirtuin 1 (SIRT1) and B-cell lymphoma 6 (BCL6) genes, involved in multiple physiological progresses regarding differentiation, proliferation and apoptosis, seem to be overexpressed in a coordinated manner in the eutopic endometrium of patients and contribute to the pathogenesis of endometriosis (50). 
Table I. An overview of genetic polymorphisms related to the development of endometriosis, as they have been confirmed by gene association studies and GWAS.

\begin{tabular}{|c|c|c|c|}
\hline SNPs & $\begin{array}{l}\text { Endometriosis- } \\
\text { associated gene }\end{array}$ & Function & (Refs.) \\
\hline rs1042522 & TP53 & Tumor suppressor protein & $(53)$ \\
\hline $\begin{array}{l}\text { rs2234693 } \\
\text { rs9340799 }\end{array}$ & ESRl & Nuclear receptor activated by the sex hormone estrogen & $(153)$ \\
\hline rs743572 & CYP17A1 & $\begin{array}{l}\text { Hydroxylase-type enzyme, ubiquitously expressed } \\
\text { in many tissues and cell types }\end{array}$ & $(61,62)$ \\
\hline $\begin{array}{l}\text { rs700519 } \\
\text { rs1048943 }\end{array}$ & CYPIA & Enzyme involved in phase I xenobiotic and drug metabolism & $(58,87)$ \\
\hline $\begin{array}{l}\text { rs } 10046 \\
\text { rs } 700518\end{array}$ & CYP19 & Drug metabolism and synthesis & $(67)$ \\
\hline rs1056836 & $C Y P 1 B 1$ & Member of cytochrome P450 superfamily & $(87)$ \\
\hline $\begin{array}{l}\text { rs } 244285 \\
\text { rs } 12248560\end{array}$ & CYP2C19 & Member of the cytochrome P450 mixed-function oxidase system & $(68)$ \\
\hline $\begin{array}{l}\text { rs4072111 } \\
\text { rs1131445 } \\
\text { rs11556218 }\end{array}$ & $I L-16$ & $\begin{array}{l}\text { Pleiotropic cytokine that functions as a chemoattractant, a modulator } \\
\text { of } \mathrm{T} \text { cell activation and an inhibitor of HIV replication }\end{array}$ & $(88,89)$ \\
\hline rs6542095 & $I L-1 A$ & Pleiotropic cytokine involved in inflammatory processes and hematopoiesis & $(172)$ \\
\hline rs1800871 & $I L-10$ & Anti-inflammatory cytokine & $(107)$ \\
\hline rs17860508 & $I L 12 B$ & Cytokine acting on $\mathrm{T}$ and natural killer cells & $(109)$ \\
\hline rs20417 & $C O X-2$ & Enzyme responsible for inflammation and pain & (97) \\
\hline $\begin{array}{l}\text { rs1632947 } \\
\text { rs1233334 }\end{array}$ & HLA-G & Histocompatibility antigen playing a role in immune tolerance in pregnancy & $(114)$ \\
\hline rs41308748 & LILRBI & Leukocyte immunoglobulin-like receptor & $(114)$ \\
\hline rs383369 & $L I L R B 2$ & Leukocyte immunoglobulin-like receptor & $(114)$ \\
\hline $\begin{array}{l}\text { rs } 10794288 \\
\text { rs10902088 }\end{array}$ & $M U C 2$ & Glycoprotein produced by many epithelial tissues & $(115)$ \\
\hline $\begin{array}{l}\text { rs882605 } \\
\text { rs } 1104760 \\
\text { rs2688513 } \\
\text { rs2258447 }\end{array}$ & $M U C 4$ & $\begin{array}{l}\text { Transmembrane glycoprotein that functions in cell growth } \\
\text { signaling pathways and tumor progression }\end{array}$ & $(115,116)$ \\
\hline $\begin{array}{l}\text { rs699947 } \\
\text { rs1570360 } \\
\text { rs9582036 }\end{array}$ & $V E G F$ & Signaling protein involved in both vasculogenesis and angiogenesis & $(130,136)$ \\
\hline $\begin{array}{l}\text { rs1341643 } \\
\text { rs2037815 } \\
\text { rs3740286 } \\
\text { rs4064 }\end{array}$ & FAS & $\begin{array}{l}\text { Member of the TNF-receptor superfamily, playing a central role } \\
\text { in the physiological regulation of programmed cell death }\end{array}$ & $(48)$ \\
\hline rs34536443 & $T Y K 2$ & Tyrosine kinase & $(118)$ \\
\hline rs2268613 & $P L G F$ & Vascular endothelial growth factor associated with angiogenesis & $(136)$ \\
\hline rs11549465 & $H I F-1 \alpha$ & Transcriptional regulator of cellular and developmental response to hypoxia & $(136)$ \\
\hline rs144240142 & $M A P 3 K 4$ & Component of a protein kinase signal transduction cascade & $(174)$ \\
\hline rs10928050 & $K A Z N$ & Protein that plays a role in desmosome assembly and cell adhesion & (46) \\
\hline rs2427284 & LAMA5 & Extracellular matrix glycoprotein & $(46)$ \\
\hline rs2235529 & $\begin{array}{l}\text { LINC00339- } \\
\text { WNT4 }\end{array}$ & $\begin{array}{l}\text { RNA gene affiliated with the non-coding RNA class - protein } \\
\text { implicated in oncogenesis and in several developmental processes }\end{array}$ & (163) \\
\hline $\begin{array}{l}\text { rs1519761 } \\
\text { rs6757804 }\end{array}$ & $R N D 3-R B M 43$ & $\begin{array}{l}\text { Negative regulator of cytoskeletal organization - } \\
\text { nucleic acid binding and nucleotide binding }\end{array}$ & (163) \\
\hline
\end{tabular}


Table I. Continued.

\begin{tabular}{lllc}
\hline SNPs & $\begin{array}{c}\text { Endometriosis- } \\
\text { associated gene }\end{array}$ & \multicolumn{1}{c}{ Function } & (Refs.) \\
\hline rs4703908 & ZNF366 & Transcription co-repressor and estrogen receptor binding & $(164)$ \\
rs12700667 & NFE2L3-HOXA10 & Membrane bound glycoprotein - DNA-binding transcription factor & $(134)$ \\
rs7521902 & WNT4 & Promotes female sex development, represses male sex development & $(166,167)$ \\
rs1333049 & & Regulator of estrogen-induced breast cancer & $(166)$ \\
rs13394619 & GREB & Plays a pivotal role in the establishment of adherens junctions & $(166)$ \\
rs10859871 & VEZT & Induction of pre- and post-synaptic differentiation of neurons & $(169)$ \\
rs2475335 & PTPRD & Regulation of angiogenesis and vascular development and permeability & $(173)$ \\
rs17773813 & KDR & Cell adhesion, cell motility, opsonization, wound healing & $(167)$ \\
rs1250248 & FN1 & Intracellular trafficking & $(164)$ \\
rs2479037 & VTI1A & &
\end{tabular}

Tumor growth/suppression loci. Chromosome 17 aneuploidy appears to be significantly higher in patients with endometriosis in contrast to healthy individuals. This augmented heterogeneity of chromosome 17 supports the scheme of a versatile pathway involving somatic genetic alterations in disease progression (51). Molecular studies of cancer explain that genomic instability, involving chromosome 17, plays a role in the development and progression of various tumor types. TP53 is a tumor suppressor gene essential for cell growth development modulation and protection form carcinogenesis, located at 17p13.1 and encoding nuclear phosphoprotein $\mathrm{p} 53$, which partakes in apoptosis, as well as DNA repair processes. The $\mathrm{C}$ allele of $\mathrm{p} 53$ codon 72 may be associated with the development of endometriosis, and can also be utilized as a potential predictive biomarker (52). One of its polymorphisms, TP53 Arg72Pro has been associated with various diseases, including endometriosis; in particular, the rs1042522 polymorphism has been linked with the risk of endometriosis in an Asian populations (53). In a prospective study of 118 patients, the results revealed that p53 arginine homozygotes had a decreased risk of the disease, while heterozygotes and proline homozygotes demonstrated an increased risk (54). Indeed, in a relevant study, p53 codon 72 Pro/Pro + Arg/Pro genotypes were found to be associated with an augmented disease risk in Asian women (55). Furthermore, the decreased expression of phosphatase and tensin homolog (PTEN), another tumor suppressor gene, has been shown to possibly contribute to the malignant progression of endometriosis (37).

Detoxification genes. CYP genes are responsible for the production of enzymes useful for the metabolism of xenobiotics. Thus, genetic variations in the afore-mentioned regions incite false cellular signals impacting metabolic pathways. AhR is a ligand-dependent transcription factor that modulates cellular differentiation and induces the activation of phase I and II drug-metabolizing enzymes. Since the AhR signaling pathway modulates the induction of CYP1A1 and CYP1B1 (partaking in phase I), potential modifications herein can evidently affect disease risk. AhRR codon 185 variation has been reported to be associated with the susceptibility to and severity of endometriosis in a Japanese population (56). This pronounced inclination in an Asian population has also been recorded elsewhere; in a meta-analysis examining the effects of $C Y P 1 A 1 A$ polymorphisms in disease risk, Ile462Val polymorphism was found to be associated with an increased risk (57). Moreover, in patients of Asian origin, polymorphism rs700519 has been shown to be related to the riskt of developing endometriosis, while among Caucasians, the same meta-analysis revealed that the putative endometriosis-associated genetic variation was rs10046 in CYP19 (58). The dioxin-induced increased expression levels of CYPIA 1 and $\gamma$-SYNUCLEIN in the ectopic endometrium have also been observed in patients with endometriosis (59).

CYP17 (cytochrome P450c17a1) is a gene responsible for encoding the enzyme for estrogen biosynthesis. In a case control study of Iraqi women from 23 to 46 years of age, a significant association was noted between endometriosis and specific SNPs of the CYP17 gene, with homozygous genotypes being associated with a diminished disease risk (60). In a case-control study, patients homozygous for the CYP17A1 C allele of the rs743572 SNP were associated with a markedly increased risk of leiomyoma (61); in particular, the CYP17A1 rs743572 genetic variation can also act as a potential risk factor for endometriosis, according to published data (62). In a case-control study of 143 patients, the presence of the rs 743572 TT genotype of CYP17A1 appeared to constitute a risk factor for endometriosis, although it did not affect disease progression. While COMT polymorphisms have been presented to affect the risk of adenomyosis, CYP17 and CYP1A1 were not recorded to be relevant to affecting endometriosis manifestation in another study (63). Furthermore, in a study of 100 women that previously underwent laparotomy/laparoscopy, the analysis of genomic DNA by real-time PCR revealed that the CYP2C19*2 heterozygote genotype was associated with an increased disease risk (64).

The decreased expression of CYP19A1 in cumulous cells of infertile women with endometriosis may also be linked to endometriosis-induced infertility (65). The AA and CC genotypes were importantly represented in the Val80 and C1558T polymorphisms of CYP19 (66) in women with the disease. In Chinese women, it has been proposed that CYP19 gene polymorphisms are not related to endometriosis susceptibility, although the CYP19 rs700518 AA genotype pertains to 
endometriosis-related infertility (67). The sequencing of the $C Y P 2 C 9$ gene region has revealed a wide number of known and novel SNPs. The genotyping of 80 SNPs in 901 patients has revealed an association for SNPs in moderate or complete linkage disequilibrium with rs244285, a functional SNP in exon 5 that abolishes $C Y P 2 C 19$ function via an alternative splice site formation, and association in an SNP in the CYP2C19 promoter, rs12248560. Thus, it can be deduced that polymorphisms in CYP2C19 can trigger susceptibility to endometriosis (68).

It is well known that individual polymorphisms are, to a varying degree, associated with endometriosis; it is, however, worth noting that genetic variations acting cooperatively can augur novel relations regarding disease risk. In a retrospective case-control study of a 340-women sample, the combined analysis of polymorphisms in PGR-CYP17A1-CYP19A1 seemingly suggested a gene-gene interaction in disease susceptibility (69). The glutathione family (GST) genes appear to play a role in endometriosis. In a previous study, when comparing the frequencies of GSTM1 and GSTT1 polymorphisms between cases and controls, the GSTM1 null genotype frequency was found to be similar in both groups, while the GSTT1 null genotype was encountered in a higher frequency in the control group (70).

The human arylamine $\mathrm{N}$-acetyltransferase 2 (NAT2) gene, on chromosomal region 8 p22 11, plays a key role in the conjugation of xenobiotic substances. The NAT2 G590A SNP may be associated with the susceptibility to endometriosis, and the 590A allele may play a protective role in the development of endometriosis. The NAT2 481C, 803A, 590A, 587A haplotypes have also been associated with a higher risk of endometriosis in an Iranian population (71).

It has been suggested that the GSTM1, GSTT1 and combined GSTM1/GSTT1 null genotypes increase susceptibility to endometriosis (72). Indeed, another meta-analysis that included 25 case-control studies investigated the association of null GSTM1 and GSTT1 genotypes with the disease risk, which was found to be positive (73). According to a systematic review, GSTT1 null deletion carriers present with a medium disease risk, at approximately $29 \%$ (74). The association between glutathione S-transferases genes variants in an Iranian population consisted of 151 cases and 156 controls was found to be positive, since the GSTM1 null genotype presented a rate of $7.3 \%$ in comparison to $1.3 \%$ in the control group, while the GSTP1 313 AG genotype was notably lower in the cases than the controls (75). The CYPIA1 m1 polymorphism, the GSTM1 null deletion and the CYP19 VNTR (TTTA) 10 allele seem to be directly associated with the penetration of the endometriosis phenotype $(76,77)$, as it occurred in a case-control study, with a larger sample size of 275 patients (77). The CYP1A1 T6235C polymorphism and GSTM1 null mutations and genetic association to endometriosis has been examined in a sample of 131 patients belonging to a North Indian population, where the GSTM1 null genotype was positively linked to endometriosis, while the homozygous mutant and allele frequency of CYP1A1 T6235C presented an important difference between the cases and controls (78). Contrarily, no profound difference has been noted between frequencies of the GSTM1 null genotype in case and control groups in the study by Seifati et al in 2012; therefore, no association has been depicted at this point regarding disease severity (79).

As regards exposure to endocrine disruptors, genetic association studies are concerned, apart from candidate genes, with the investigation of impact and outcomes stemming from exposure to endocrine disruptors. It is widely known that exposure to numerous environmental chemicals can affect physiological processes and induce adverse effects. Endocrine disruptors possess the ability to interfere with hormonal functions. Organochlorines are endocrine disruptors acting as xenoestrogens and inducing steroid hydroxylation, thus hindering reproductive capacity and potentially neoplasia (80). The endometrium is vulnerable to endocrine disruptors, since it undergoes endocrine and immune signaling in a circular mode. 2,3,7,8-Tetrachlorodibenzo-p-dioxin (TCDD) has lipophilic traits and presents the ability to accumulate in adipose tissue (81), and can affect the levels of steroid receptors and their respective gene expression (82). TCDD can intercept cannabinoid signaling important for the anti-inflammatory effects of progesterone, while several types of TCDD can disrupt the procedures of the AhR pathway, as well as immune activity (83). TCDD also possesses the ability to permeate the placenta, and has been described to cause homeobox-Tbox remodeling in the prenatal period (84).

Increasing evidence indicates that a number of adult diseases occur due to environmental exposure during the fetal period and early-life. It has been observed through experimental tests that exposure to endocrine disruptors affects fertility in male and female mice and may lead to spontaneous pre-term birth (85). The impairment of endometrial progesterone sensitivity in a murine model has been supported, and has been linked to an inflammatory pathway affecting not only the reproductive success, but also contributing to the manifestation of adenomyosis and adhesions (86). In a sample of 138 patients diagnosed with endometriosis-induced infertility, the assessment of plasma polychlorinated biphenyl (PCB) levels revealed that patients carrying the $C Y P 1 A 1$ rs1048943 genetic variation, demonstrated an decreased risk of developing advanced endometriosis, in the cases where dioxin plasma levels were elevated. Circulating PCB levels are also associated with advanced endometriosis, in carriers of the CYP1B1 rs1056836 polymorphism (87).

Inflammation and autoimmunity-related genes. Diverse associations have been observed between interleukin genetic alterations and endometriosis pathophysiology. Interleukin (IL)-16 is a pro-inflammatory cytokine, chemotactic for $\mathrm{CD}^{+} \mathrm{T}$ lymphocytes, monocytes and eosinophils, known to be associated with various ailments. Genotype distribution in two exon variations have been identified as notably different between diseased patients and healthy women. Moreover, a correlation has been underlined between the rs4072111 and rs1131445 SNPs with disease progression, implying a potential role of $I L-16$ polymorphisms as a susceptibility factor for endometriosis (88). The role of $I L-16$ genetic variations has also been studied in a total sample of 159 patients of Greek origin. A positive correlation was apparent between the GG and GT genotype, as well as the ' $G$ ' allele of rs11556218 in patients with endometriosis, while the rs4072111 SNP of the $I L-16$ gene was not associated with an increased disease susceptibility, regardless of disease stage (89).

The intracellular adhesion molecule-1 (ICAM-1) gene is located on chromosome 19 (19p13) and its expression ensures immunocompetence. The additive effect of several 
polymorphisms of the immune system can reportedly lead to alterations in immune balance, thus contributing to the establishment of endometrial cells in ectopic sites (90). A synergistic action has been described in the $I L-6-634 \mathrm{C} / \mathrm{G}$ and ICAM-I $469 \mathrm{~K} / \mathrm{E}$ polymorphism acting together to influence endometriosis in a Japanese female sample $(n=202)(91)$. In contrast to the findings of previous studies discussed above, variations in $\mathrm{K} 469 \mathrm{E}$ and G241R of ICAM-1, as well as G634C of IL-6 have been previously described to not be associated with a greater disease vulnerability, in a sample of 200 Brazilian women (92). No significant association either has been observed in the variation of IL-6 promoter $-174 \mathrm{G} / \mathrm{C}$ in a South Indian population (93). However, the ICAM-1 polymorphisms, G241R and $\mathrm{K} 469 \mathrm{E}$, have been suggested to be independently associated with the risk of endometriosis in a Japanese population (94).

The excessive expression of cyclooxygenase (COX)-2 has been associated with the pathogenesis of endometriosis. In a study where tissue samples of 28 premenopausal women were examined, a denser COX-2 stain was observed in the ectopic endometrial tissue, with the $C O X-2$ mRNA levels presented a 5-fold elevation in the patients' ectopic tissue, compared to the eutopic endometrium. These findings suggested that aberrant COX-2 activation with abnormal prostaglandin production may contribute not only to the pathophysiology, but also to disease progression (95). Furthermore, the medial expression of the COX-2 gene (mRNA PTGGS2) in females with endometriosis has been shown to be elevated in comparison to the controls, while the distribution of alleles in fertile women with endometriosis of stages II/III has demonstrated an association of statistical significance of the ancestral allele $-765 \mathrm{G}$, with an elevated risk (96). Similarly, the G-765C (rs20417) polymorphism of the $C O X-2$ gene pertains to an elevated hazard of endometriosis of stages III and IV, with the eutopic endometrial tissue of patients presenting an elevated expression of COX-2 in comparison to the controls (97).

The $B s r B I$ restriction enzyme creates a $\mathrm{C}$ to A transition at position 52 in exon $1 \mathrm{C}$ of the IL-1 receptor type I (IL-IRI) gene. Protective action against disease development demonstrated a BsrBI created C/A heterozygote genotype according to a previous study (98). The chromosomal 2q13 locus belongs to a broader region with intense presence of inflammatory gene transcripts, since it includes the IL-1 gene cluster. Therefore, modifications in IL-1 family expression can lead to significant disease susceptibility (99). The sequencing of ILIA exons in 377 Japanese female patients has, in fact, revealed 4 SNPs strongly associated with endometriosis (100).

There is a scientific debate regarding the association of $I L-1 \beta$ and its role in endometriosis. Non-relation has been underlined between endometriosis and the $I L-1 \beta-511$ promoter, $I L-1 \beta$ exon 5 and $I L-1$ receptor antagonist genetic variations, since proportions of various polymorphisms did not seem to differ significantly between a group of patients $(n=120)$ and healthy controls $(n=103)$ in a previous study (101). Notably, the association between $I L-1 \beta(+3953)$ polymorphism endometriosis in a Turkish population was assessed as negative, since statistically insignificant proved to be the increased frequency of the respective genotypes (102). On the other hand, additional evidence exists for a positive correlation between the $I L 1 A$ locus and endometriosis (103). $I L-2 R \beta-627 * \mathrm{C}$ homozygotes are linked with a higher predisposition to endometriosis (104).
By contrast, the $I L-2 \beta$ receptor gene C624T variation in Korean women with the disease has been shown to be independent of the disease risk (105).

A functional promoter variant in the $I L-10$ gene has been suggested to contribute in the development of endometriosis. The IL-10 ACC/ACC homozygous genotype seems to be associated with endometriosis (106). Subjects carrying the minor allele C of rs1800871 SNP located on a functional promoter of IL-10 appear to have an approximately 2-fold decreased risk of endometriosis compared to those with the TT genotype, with the $\mathrm{T}$ allele presenting reduced gene expression levels compared to the $\mathrm{C}$ allele, insinuating a deficient suppression of inflammation that fosters the development of endometriosis (107).

It has been suggested that women with advanced endometriosis present higher IL-4 plasma levels, although this event is not influenced by the $I L-4-590 \mathrm{C} / \mathrm{T}$ genetic polymorphism (108). In addition, the rs 17860508 polymorphism in the $I L 12 \mathrm{~B}$ promoter region may influence the risk of developing ovarian endometriosis, through the modification of the endometrial expression of $I L 12 B$ in the Northern Chinese women, in a sample of 815 cases (109).

Genetic polymorphisms of matrix metalloproteinase $(M M P)-12$ and -13 have been suggested to trigger superficial, although not deep infiltrating endometriosis, an event that can possibly be interpreted as the provocation of a protective mechanism that these polymorphisms offer, which can possibly act preventively against a more in-depth penetration in tissues (110). The upregulation of survivin and MMP-2, -9 and MT1-MMP may act in combination as regards the invasive behavior of endometriosis (111). While the reticulocyte-type 15-lipooxygenase-1 (ALOX15) gene is involved in implantation, ALOX15 -292 C/T does not appear to be associated with disease or infertility risk; other ALOX15 gene polymorphisms may possibly exhibit a different pattern, thus, should not be excluded from future research prospects (112).

Killer immunoglobulin-like receptors (KIR) are inhibitory receptors on the surface of HLA molecules. It has been demonstrated that patients who are KIR2DS5-positive present a 13-fold lower risk of peritoneal disease invasion than their KIR2DS5-negative counterparts, while KIR2DSdel-positive ones have similarly an 11-fold lower risk of peritoneal disease. On the whole, it has been suggested that KIR2DS5 may act protectively against endometriosis, while KIR2DSdel may be associated with advanced disease, possibly through the omission of KIR2DS5 (113). Placental trophoblasts express, in particular, human leukocyte antigen-G (HLA-G), essential for pregnancy upkeep. This can also be expressed by the ectopic endometrium in the peritoneal cavity, thus being recognized by cells of the immune system, through the receptors LILRB1 and LILRB2. By performing genotype assays in a total of 590 individuals, researchers have deduced that genotypes LILRBI rs41308748 AA and LILRB2 rs383369 AG, as well as the $H L A-G$ rs 1632947 GG and $H L A-G$ rs1233334 CT are regulators of disease progression and susceptibility (114).

Mucins constitute a category of highly glycosylated proteins, responsible for the protection and lubrication of epithelial surfaces of respiratory, gastrointestinal and reproductive tracts, and it has been suggested that several mucins are involved in endometriosis-induced infertility. In a case-control study of 195 patients, the assay of the mucin 2 (MUC2) gene revealed 
an association of polymorphisms rs10794288 and rs10902088 with endometriosis and a low fertility (115). As regards mucin 4 (MUC4), a case-control study involving 140 patients of Taiwanese origin, suggested that the T/G genotype of the rs882605 SNP and the frequency of the haplotype TT of rs882605 and rs1104760 were elevated in women with endometriosis to a statistically significant degree, while the $\mathrm{C}$ allele at the SNP rs1104760, the C allele at rs 2688513 , the $\mathrm{G}$ allele of rs882605 and the A allele of rs 2258447 were associated with advanced endometriosis. Furthermore, particularly the $\mathrm{G}$ allele of rs 882605 was described as an important risk factor for infertility in women with endometriosis (116).

In the promoter tumor necrosis factor- $\alpha$ gene $(T N F-\alpha)$, genetic variations have been suggested to be associated with an advanced stage of endometriosis in a Korean female sample (117). Tyrosine kinase 2 (TYK2) is a part of Janus kinase (JAK) that binds to the type I interferon $-\alpha$ receptor (IFNAR) and plays a critical role in autoimmunity and inflammation. It has been suggested that the polymorphism rs34536443 is associated with protection against endometriosis-induced infertility, particularly in advanced disease stages. In addition, the 'CTATG' haplotype has been linked to a reduced susceptibility to endometriosis in a Brazilian female population (118). Acid phosphatase locus 1 (ACPI) is involved in allergy manifestation; in a study including 113 participants, the $A C P I^{*} C$ allele was more frequently encountered in women with endometriosis than in healthy individuals (119).

The protein tyrosine phosphatase non-receptor 22 (PTPN22) gene, located on chromosome 1p13.3-13.1, encodes a lymphoid-specific phosphatase known as Lyp, a potent downregulator of T-cell activation. In a case control study of 140 patients and 180 controls from Brazil, the investigation of a PTPN22 (C1858T) polymorphism brought out the importance of this polymorphism as a predisposing factor, particularly for the advanced disease stages of the disease (120). Despite the fact that PTPN22 variations do not, at present, provide a lucid picture of their direct involvement in endometriosis (121), nevertheless PTPN22 may act cooperatively with other genetic factors, thus resulting in the regulation of disease course and immune interposition, due to an important elevation of PTPN22 $* \mathrm{~T}$ allele observed in patients (122).

FCRL3_3 is a polymorphism of Fc-receptor like-3 gene (FCRL3), a gene that incites activation of NF- $\kappa \beta / M A P K$ pathways. This variation has been associated with an increased disease risk of endometriosis-induced infertility, regardless of the symptoms and disease stage (123). Caspase recruitment domain family member $(C A R D) 10$ and CARD11 mutations have been suggested to be linked with endometriosis. CARD11 belongs to the CARD protein family, since it binds with B-cell CLL/lymphoma 10 , and activates the inflammation-associated $\mathrm{NF}-\kappa \beta$ signaling pathway as well. Four novel somatic mutations in CARD10 and CARD11 genes detected among 101 patients with ovarian endometriosis, suggesting their role in the development of ovarian endometriosis (124).

Angiogenesis-related genes. A positive association has been observed between genetic polymorphisms in fibroblast growth factor (FGF) 2 and the risk of endometriosis and adenomyosis in a North Chinese women population. The FGF2 754C/G polymorphism has been shown to be associated with the risk of developing endometriosis and adenomyosis (125). Fibroblast growth factor receptor 2 (FGFR2) variations, although being associated with endometrial and breast cancer, have not been proven to be associated with disease susceptibility, according to a case-control study of 958 cases and 959 controls (126).

Vascular endothelial growth factor (VEGF) is considered one of the most prominent contributors to the development of endometriosis. The $V E G F+405 \mathrm{C} / \mathrm{G}$ polymorphism is reportedly associated with the risk of endometriosis atan advanced stage in a Korean population (127). By contrast, according to a meta-analysis including 2,947 cases, the $V E G F+405 \mathrm{G}>\mathrm{C}$ genetic polymorphism was not profoundly associated with disease risk, since no important interrelation was extrapolated, neither in terms of genetic models nor ethnicities (128). However, the VEGF -2578 A/C SNP has been reported to be a potential factor for disease susceptibility among an Estonian women population consisting of 150 subjects (129). In a systematic review and meta-analysis, where 14 case-control published articles were studied, the rs699947 (A>C) and rs1570360 (G>A) polymorphisms of the $V E G F$ gene were linked with a reduced disease risk, while rs3025039 (C>T) as enhancing contributors to disease risk. The rs833061 ( $>$ C $)$ and $\mathrm{rs} 2010963(\mathrm{G}>\mathrm{C})$ polymorphisms do not appear to affect disease susceptibility (130). The association between VEGF gene variations and endometriosis was found in a meta-analysis that processed the results retrieved from 11 studies, with the VEGF +936TC gene polymorphism proving to be a risk factor of endometriosis (131). Similarly, the VEGF 2460/21154/22578 TGC, CAA, TAA and TAC haplotypes were associated with endometriosis. In addition, the 21154A and 22578A alleles were shown to act protectively against the development of endometriosis in North Chinese women (132). A positive association between $V E G F-1154 \mathrm{G}>\mathrm{A}$ and disease risk has also been noted in a Brazilian population, with the CCGG haplotype probably acting protectively against disease development (133). An independent association was found between $V E G F \mathrm{C} / \mathrm{T},+405 \mathrm{G} / \mathrm{C}$ and $+936 \mathrm{C} / \mathrm{T}$ SNPs and endometriosis-related infertility (134), while, contradictory results emerged according to a meta-analysis, where the VEGF +936T/C genetic polymorphism induced susceptibility to endometriosis, particularly as regards advanced disease stages (135).

A noteworthy correlation has also been shown to occur between the rs2268613 variation of the placental growth factor (PLGF) gene and PLGF serum levels (136). Women with the AA variant of the rs2268613 PLGF gene exhibit considerably decreased PLGF serum levels, compared to those with the AG variant. Circulating levels of VGF are described as increased in patients with endometriosis. In the same study, a correlation, albeit weak, occurred between endometriosis and variations of PLGF (rs2268614), HIF-1 $\alpha$ (rs11549465) and VEGFRl (rs9582036).

Other angiogenesis-related genes have been also observed to be differentially expressed in patients. Importantly, increased levels of AKT serine/threonine kinase 1 (AKT1), thymidine phosphorylase (TYMP), Jagged 1 (JAG1), LAMA5 and TIMP metallopeptidase inhibitor 1 (TIMP1) were found in the eutopic endometrium of patients with endometriosis compared to healthy controls (137). Furthermore, the increased expression of genes responsible for cellular migration and angiogenesis, namely inhibitor of dna binding 2 (ID2), proline and arginine rich end leucine rich repeat protein (PRELP) and sparc 
related modular calcium binding 2 (SMOC2) in women with endometriosis, suggests that this altered expression is linked to the development of the ectopic endometrium (138). Nitric oxide (NO) is known to partake in a number of physiological procedures; the endothelial subtype of this enzyme, endothelial NO synthase (eNOS), instigates VEGF-induced vascular permeability and angiogenesis, hence playing a key role in endometriosis by promoting angiogenesis (139). While a positive association has been noted between the eNOS Glu298Asp variation and advanced-stage disease (140), another study did not observe for the same polymorphism, any association with for disease risk in a South Indian population (141).

Hormonal function. Follicle-stimulating hormone (FSH) plays an important role in steroidogenesis and acts through a trans-membrane glycoprotein, the FSH receptor (FSHR). Since endometriosis is an estrogen-dependent disease, it can be deduced that genetic alterations in FSHR would affect FSH plasma concentrations and reproductive capacity. While no significant association has been noted between patients with endometriosis and controls, a positive association seems to exist among patient groups regarding fertility and disease stage in terms of FSHR genetic variance. Specifically, in a relevant study, the 680Ser-Ser/GG genotype and GG/307Ala680Ser haplotype were associated with an increased risk of developing endometriosis, while the presence of the GA/307Ala680Asn haplotype was associated with a reduced risk of disease development and progression (142).

Polymorphisms in LH receptor (insLQ) seem higher in patients with endometriosis and infertility, in comparison to healthy fertile controls (143). SNP in the $A M H$ (anti-Müllerian hormone) gene is related to endometriosis-induced infertility, while SNPs in growth differentiation factor-9 (GDF-9) and the $-482 \mathrm{~A} G \mathrm{SNP}$ in the AMHR2 gene were found to not be related (144). The association between polymorphisms in progesterone receptor $+331 \mathrm{G} / \mathrm{A}$ and endometriosis has been presented as positive in patients with deep infiltrating endometriosis, as a considerable elevation has been highlighted as regards the risk of developing deep-infiltrating endometriosis among women bearing the $+331 \mathrm{~A}$ allele. While this particular study does not support a generic association between endometriosis and the $P R+331 \mathrm{G} / \mathrm{A}$ polymorphism, it rather proposes a possible role of this genetic variation in the invasive behavior of endometrial cells, that is dependent upon PR (145). MicroRNAs (miRNAs or miRs) are short non-coding RNAs of approximately 18-22 nt in length, firstly discovered in 1993 (146). miRNAs have been reported to regulate gene expression, while the stability and specificity that they present renders them appropriate for biomarkers (147). The downregulation of miRNA200b has been observed to occur both in endometriosis and malignancy, provoking epithelial-to-mesenchymal transition and consequently invasive growth (148). miRNA-196a has been stated to upregulate the MEK/ERK signaling pathway, inducing the downregulation of progesterone receptor in the eutopic endometrium of women with minimum/ mild endometriosis (149). As for miRNA Let-7b, it has been proposed as a novel therapeutic option for endometriosis, since it influences a number of pathways at the same time without inducing systemic hormonal adverse effects (150).
Polymorphisms in the $E R$ - $\alpha$ gene encoding aromatase are described as disease risk factors (151). In a case-control study, patients homozygous for the ESRI C allele polymorphism rs2234693 were found to be associated with a significantly augmented risk of leiomyoma (61). However, in a case-control study of 100 cases, ESR1 polymorphisms did not seem to contribute to disease susceptibility (152). In a similar study, infertile women with the ESRI rs9340799 GG genotype presented a 4-fold higher risk of endometriosis (153). Moreover, the $A l u \mathrm{I}$ genetic variation of the $E R \beta$ gene has been associated with an increased risk of severe endometriosis in a Japanese population (154). In a meta-analysis of 24 case-control studies that examined ESR1 polymorphisms, $P$ vull proved to be associated with endometriosis regarding stage I-III only under the recessive model. The short allele and $\mathrm{TA}_{13}$ of $(\mathrm{TA})_{\mathrm{n}}$ have been related to a higher risk of endometriosis, while $\mathrm{TA}_{20}$ repeats have been associated with a decreased disease risk. All in all, the results of this meta-analysis suggest that the (TA) polymorphisms may participate in the susceptibility to and protection against the pathogenesis of endometriosis (155).

Forkhead Box D3 (FOXD3) is a protein coding gene essential for the upkeep of pluripotent cells during the implantation stages of embryogenesis. FOXD3 has been found to be differentially expressed in the endometrium of healthy individuals and controls, as it can be deduced by the decreased levels of the protein upon the decidualization of normal human endometrial stromal cells in vitro, and differential endometrial expression in the stroma, in endometriosis (156). $17 \beta$ hydroxysteroid dehydrogenase 1 (HSD17B1) converts estrone into $17 \beta$ estradiol. In a study comprised of 290 cases and 410 controls, the HSD17B1 937G variant was displayed as a risk factor for infertility in disease stage I and II of a Polish Caucasian women population (157). On the other hand, no significant association was found between endometriosis stage I-II infertile women and the expression of the adhesion molecules, osteopontin and avb3 integrin (158). The expression of glycodelin-A (GdA) has been reported to be dysregulated in women with endometriosis, implying the association with hindered endometrial receptivity (159).

The expression of the p16 and pRb proteins is associated with endometriomas and adenomyosis, since these proteins may play a role in the regulation of cell growth in adenomyosis and ovarian endometriotic cysts; p16 appears to play a prominent role in proliferative-phase adenomyotic tissue, whereas $\mathrm{pRb}$ is more prominent in endometriomas (160).

\section{Genome-wide association studies}

GWAS investigate new genomic regions associated with multifactorial ailments, through the usage of computational model techniques, aiming at the comparison of genotypes between patients and healthy individuals for the identification of endometriosis-related SNPs (161).

In a meta-analysis based on GWAS performed in a Japanese female population, 4 prevalent SNPs were pinpointed near and within the ILIA region, rendering it a candidate gene (162). Another GWAS, including 2,019 diagnosed patients brought out the following results: LINC00339-WNT4 on 1p36.12 (rs2235529), RND3-RBM43 on 2q23.3 (rs1519761 and rs6757804), RNF144B-ID4 on 6p22.3 and HNRNPA3P1-LOC100130539 
on $10 \mathrm{q} 11.21$. A sequence of $150 \mathrm{~kb}$ around the WNT4 locus was also identified, including LINC00339 and CDC42 (163). ZNF366, previously having been associated with breast cancer development, was proposed as a new contributor to the disease, since 4 SNPs were found to be significantly associated with endometrioma risk (rs227849, rs4703908, rs2479037 and rs966674). The genetic variant rs4703908 located near ZNF366 has been linked to an increased risk of endometrioma and deep infiltrating endometriosis (164). Nakaoka et al (165) aimed at unlocking the molecular mechanism of 9p21 endometriosis risk genetic locus, by demonstrating allelic imbalances in the tier of transcription events, entailing from factor binding to gene expression. Through the sequencing and examination of DNAase-seq data of the 9p21 chromosomal region, rs17761446 was the predominant genetic variant in absolute linkage disequilibrium with the original GWAS SNP (rs10965235) and located on Dbase I hypersensitive site. By the usage of the chromosome conformation capture technique and high-throughput sequencing technologies, it was noted that the $\mathrm{G}$ allele of rs17761446 demonstrated a higher chromatin interaction with the ANRIL promoter; allele analysis revealed that the afore-mentioned polymorphism exerted regulating action where the $\mathrm{G}$ allele was linked to an elevated ANRIL expression. In another GWAS, including 4,604 patients, aimed to confirm previous associations and discover novel endometriosis risk loci in populations of European and Japanese descent, genetic variant rs12700667 on 7p15.2 was detected in both Japanese and Europeans, while a correlation between rs7521902 at 1p36.12 close to WNT4 has also been confirmed. Other associations included: rs13394619 on GREB at site 2p25.1, rs10859871 on VEZT at 12q22, and some additional at 2p14, 6p22.3 and 9p21.3 (rs4141819, rs7739264 and rs1537377, respectively) (166). Risk allele frequency of the SNPs rs12700667 and rs4141819 regarding their association with infertility, that have been identified in previous GWAS, has also been confirmed in a sample of 315 Polish patients with III/IV disease stage (134).

Pagliardini et al (167) aimed at confirming the association of GWAS-detected susceptibility loci, previously proposed by Painter et al (168) and Uno et al (169). It emerged that the rs1333049 risk allele $\mathrm{G}$ frequency was higher in patients with endometriosis compared to the controls, and the exact locus was also suggested for Caucasian populations. Moreover, rs7521902 was associated with the disease at a level of significance, rs1250248 was only detected in severe stages, and an interplay was found between rs7521902 and rs1250248, particularly in ovarian disease. This meta-analysis confirmed WNT4, CDKN2BAS and FN1 as genomic regions associated with the disease. In a GWAS among 1,364 cases involving patients with advanced-stage endometriosis, an association was found at the 7p15.2 rs12700667 locus, for every disease stage. It is noteworthy to mention that the SNP rs12700667 region is placed near the candidate genes, nuclear factor, erythroid 2 like 3 (NFE2L3) and HOXA10 (168). GWAS meta-analysis revealed 13 loci associated with endometriosis, as well as endometrial cancer. Furthermore, the SNP rs2475335, located inside the protein tyrosine phosphatase, receptor type D (PTPRD) gene, is disease-relevant at an important genomewide extent; PTPRD is involved in the signal transducer and activator of transcription 3 (STAT3) pathway, which has been implicated with both endometriosis and endometrial cancer (170).
An intergenic locus on 7p15.2 has been described to be significantly associated with endometriosis, as it was observed in a GWAS. In the same study, 4 genetic polymorphisms were detected (inside or near KIFAP3, CAB39L, WNT4 and GRB14), that were involved not only in endometriosis, but also in the waist-to-hip ration adjusted for BMI. In general, endometriosis has been reported to be associated with a reduced body mass index (BMI) (171). A significant reproduction of results stemming from GWAS and candidate genes studies has been observed in a meta-analysis by Sapkota et al in 2015 (172), where 9 identified SNPs as susceptibility loci were reported. It has also been demonstrated that the SNPs rs7521902, rs13394619, rs6542095, rs12700667, rs7739264 and rs1537377 exhibit a significant association with endometriosis. In a GWAS including 1,840 patients of Icelandic origin, a novel risk locus at $4 \mathrm{q} 12$ (rs17773813) was found. This genetic site is located near the KDR gene, which encodes one of the two VEGFR2 receptors (173). In a study by Uimari et al in 2017, a novel SNP was detected, rs144240142, located inside $M A P 3 K 4$. In particular, it was shown to be expressed in a different pattern in the eutopic endometrium among cases with minimal/mild disease and controls. In total, 14 pathways were presented to hold an association with endometriosis, including the Wnt and ERK/MAPK pathways (174).

\section{Conclusions and future perspectives}

It is well established that the pathogenesis of endometriosis combines both genetic and environmental influences. Familial studies, linkage analysis, genetic association studies and GWAS have shed light onto the pathophysiology of endometriosis through ample evidence associating cellular procedures with disease development. However, many aspects of the disease etiology remain obscure.

Genetic association studies, however, exhibit several limitations. While in some individuals carrying a mutation, disease may not manifest, in other cases the very same putative causal mutation may be absent. Hence, etiological mutations are not a prerequisite for disease onset and control sampling should be meticulously examined. Apart from the unequal association between etiological mutations and disease phenotype, the mutation locus plays an important role. Tight correlations being encountered among neighboring genetic polymorphisms complicate research attempts; in the meanwhile, the issue of linkage disequilibrium occurring in non-adjacent regions could augment degree of challenge. Lastly, it should not be disregarded that even subtle genetic alterations that do not ostensibly lead to expression of a different protein, can affect function and stability of the encoded product (175). GWAS, in turn, present this opportunity to reveal genetic interactions and additional candidate genes. The GWAS method offers the leverage of rapid detection of thousand SNPs for the investigation of possible correlations and provides the benefit of limited bias in comparison to candidate gene studies. By contrast, GWAS demand large samples in order to bring solid results (176).

Evidently, GWAS have trailed a notable trajectory in the detection of genetic variations that induce vulnerability to multiple diseases. GWAS utility extents from disease causality and pathogenesis elucidation, to the prominence of novel 
subtypes and prediction of disease risk. Furthermore, progress in next generation sequencing provides the opportunity to search for less common variants with significant effects, through a hypothesis-neutral approach. Thus, whole exome sequencing (WES) allows the analysis of all exonic regions of a genome by next-generation sequencing (NGS) (177). However, a weakness of the new technological approaches of WES and whole genome sequencing (WGS), which have become impressively available and affordable, deals with their potential for identification of genetic factors involved mainly in monogenic diseases. Further studies encompassing genomics, cellular biology and clinical research would enhance these results and convey this knowledge in clinical practice (178).

\section{Acknowledgements}

Not applicable.

\section{Funding}

No funding was received.

\section{Availability of data and materials}

Not applicable.

\section{Authors' contributions}

LV, GNG, KK, IM, DAS and MM conceived and designed the study. LV, DAS, MM, KK, MIZ, IM and CM researched the literature, performed critical analysis and review of the literature and drafted the manuscript. GNG, MIZ and DAS drafted the manuscript. GNG, DAS and IM critically revised the article for important intellectual content.

\section{Ethics approval and consent to participate}

Not applicable.

\section{Patient consent for publication}

Not applicable.

\section{Competing interests}

DAS is the Editor-in-Chief for the journal, but had no personal involvement in the reviewing process, or any influence in terms of adjudicating on the final decision, for this article.

\section{References}

1. Giudice LC and Kao LC: Endometriosis. Lancet 364: 1789-1799, 2004.

2. Zondervan KT, Becker CM, Koga K, Missmer SA, Taylor RN and Viganò P: Endometriosis. Nat Rev Dis Primers 4: 9, 2018.

3. Vassilopoulou L, Matalliotakis M, Zervou MI, Matalliotaki C, Spandidos DA, Matalliotakis I and Goulielmos GN: Endometriosis and in vitro fertilisation (Review). Exp Ther Med 16: 1043-1051, 2018

4. Sampson JA: Metastatic or embolic endometriosis, due to the mestrual dissemination of endometrial tissue into the venous circulation. Am J Pathol 3: 93-153, 43, 1927.
5. Li X, Zhang Y, Zhao L, Wang L, Wu Z, Mei Q, Nie J, Li X, Li Y, Fu X, et al: Whole-exome sequencing of endometriosis identifies frequent alterations in genes involved in cell adhesion and chromatin-remodeling complexes. Hum Mol Genet 23: 6008-6021, 2014.

6. Jeung I, Cheon K and Kim MR: Decreased Cytotoxicity of Peripheral and Peritoneal Natural Killer Cell in Endometriosis. BioMed Res Int 2016: 2916070, 2016.

7. Symons LK, Miller JE, Kay VR, Marks RM, Liblik K, Koti M and Tayade C: The Immunopathophysiology of Endometriosis. Trends Mol Med 24: 748-762, 2018.

8. Becker CM, Laufer MR, Stratton P, Hummelshoj L, Missmer SA, Zondervan KT, Adamson GD, Adamson GD, Allaire C, Anchan R, et al; WERF EPHect Working Group: Foundation Endometriosis Phenome and Biobanking Harmonisation Project: I. Surgical phenotype data collection in endometriosis research. Fertil Steril 102: 1213-1222, 2014.

9. Goodall JR: A Study of Endometriosis. J.B. Lippinett Company, Philadelphia, 1943.

10. Matthews AG, Finkelstein DM and Betensky RA: Analysis of familial aggregation studies with complex ascertainment schemes. Stat Med 27: 5076-5092, 2008.

11. Coxhead D and Thomas EJ: Familial inheritance of endometriosis in a British population. A case control study. J Obstet Gynaecol Lahore 13: 42-44, 1993.

12. Nouri K, Ott J, Krupitz B, Huber JC and Wenzl R: Family incidence of endometriosis in first-, second-, and third-degree relatives: Case-control study. Reprod Biol Endocrinol 8: 85, 2010.

13. Kashima K, Ishimaru T, Okamura H, Suginami H, Ikuma K, Murakami T, Iwashita M and Tanaka K: Familial risk among Japanese patients with endometriosis. Int J Gynaecol Obstet 84: 61-64, 2004.

14. dos Reis RM, de Sá MF, de Moura MD, Nogueira AA, Ribeiro JU, Ramos ES and Ferriani RA: Familial risk among patients with endometriosis. J Assist Reprod Genet 16: 500-503, 1999.

15. Hull D, Gibson C, Hart A, Dowsett S, Meade M and Ward K: The heritability of endometriosis in large Utah families. Fertil Steril 77: S21, 2002.

16. Stefansson H, Geirsson RT, Steinthorsdottir V, Jonsson H, Manolescu A, Kong A, Ingadottir G, Gulcher J and Stefansson K: Genetic factors contribute to the risk of developing endometriosis. Hum Reprod 17: 555-559, 2002.

17. Matalliotakis M, Goulielmos G, Zervou M, Matalliotaki C, Koumantakis $\mathrm{G}$ and Matalliotakis I: The familial risk of endometriosis among the female relatives of patients with endometriosis in Greece. JEPPD 9: 184-187, 2017.

18. Matalliotakis IM, Cakmak H, Krasonikolakis GD, Dermitzaki D, Fragouli Y, Vlastos G and Arici A: Endometriosis related to family history of malignancies in the Yale series. Surg Oncol 19: 33-37, 2010.

19. Zondervan KT, Weeks DE, Colman R, Cardon LR, Hadfield R, Schleffler J, Trainor AG, Coe CL, Kemnitz JW and Kennedy SH: Familial aggregation of endometriosis in a large pedigree of rhesus macaques. Hum Reprod 19: 448-455, 2004.

20. Sahu M and Prasuna JG: Twin studies: A unique epidemiological tool. Indian J Community Med 41: 177-182, 2016.

21. Treloar SA, O'Connor DT, O'Connor VM and Martin NG: Genetic influences on endometriosis in an Australian twin sample.sueT@ qimr.edu.au. Fertil Steril 71: 701-710, 1999.

22. Hadfield RM, Mardon HJ, Barlow DH and Kennedy SH: Endometriosis in monozygotic twins. Fertil Steril 68: 941-942, 1997.

23. Saha R, Pettersson HJ, Svedberg P, Olovsson M, Bergqvist A, Marions L, Tornvall P and Kuja-Halkola R: Heritability of endometriosis. Fertil Steril 104: 947-952, 2015.

24. Schwartz AG, Bailey-Wilson JE and Amos CI: Genetic Susceptibility to Lung Cancer. 2nd Edition. Elsevier Inc., Amsterdam, 2018.

25. Dawn Teare $\mathrm{M}$ and Barrett JH: Genetic linkage studies. Lancet 366: 1036-1044, 2005.

26. Ott J, Wang J and Leal SM: Genetic linkage analysis in the age of whole-genome sequencing. Nat Rev Genet 16: 275-284, 2015.

27. Krishnamoorthy K and Decherney AH: Genetics of endometriosis. Clin Obstet Gynecol 60: 531-538, 2017.

28. Kennedy S: The genetics of endometriosis. Eur J Obstet Gynecol Reprod Biol 82: 129-133, 1999.

29. Treloar S, Hadfield R, Montgomery G, Lambert A, Wicks J, Barlow DH, O'Connor DT and Kennedy S; International Endogene Study Group: The International Endogene Study: A collection of families for genetic research in endometriosis. Fertil Steril 78: 679-685, 2002 . 
30. Treloar SA, Wicks J, Nyholt DR, Montgomery GW, Bahlo M, Smith V, Dawson G, Mackay IJ, Weeks DE, Bennett ST, et al: Genomewide linkage study in 1,176 affected sister pair families identifies a significant susceptibility locus for endometriosis on chromosome 10q26. Am J Hum Genet 77: 365-376, 2005.

31. Zondervan KT, Treloar SA, Lin J, Weeks DE, Nyholt DR, Mangion J, MacKay IJ, Cardon LR, Martin NG, Kennedy SH, et al: Significant evidence of one or more susceptibility loci for endometriosis with near-Mendelian inheritance on chromosome 7p13-15. Hum Reprod 22: 717-728, 2007.

32. Painter JN, Nyholt DR, Morris A, Zhao ZZ, Henders AK, Lambert A, Wallace L, Martin NG, Kennedy SH, Treloar SA, et al: High-density fine-mapping of a chromosome 10q26 linkage peak suggests association between endometriosis and variants close to CYP2C19. Fertil Steril 95: 2236-2240, 2011.

33. Lewis $\mathrm{CM}$ and Knight $\mathrm{J}$ : Introduction to genetic association studies. Cold Spring Harb Protoc 2012: 297-306, 2012.

34. Lv MQ, Wang J, Yu XQ, Hong HH, Ren WJ, Ge P and Zhou DX: Association between X-ray repair cross-complementing group 1 (XRCC1) Arg399Gln polymorphism and endometriosis: A systematic review and meta-analysis. Eur J Obstet Gynecol Reprod Biol 218: 12-20, 2017.

35. Bau DT, Hsieh YY, Wan L, Wang RF, Liao CC, Lee CC, Lin CC, Tsai CH and Tsai FJ: Polymorphism of XRCC1 codon arg 399 Gln is associated with higher susceptibility to endometriosis. Chin J Physiol 50: 326-329, 2007.

36. Hsieh YY, Bau DT, Chang CC, Tsai CH, Chen CP and Tsai FJ: XRCC4 codon $247 * \mathrm{~A}$ and XRCC4 promoter $-1394 * \mathrm{~T}$ related genotypes but not XRCC4 intron 3 gene polymorphism are associated with higher susceptibility for endometriosis. Mol Reprod Dev 75: 946-951, 2008.

37. Martini M, Ciccarone M, Garganese G, Maggiore C, Evangelista A, Rahimi S, Zannoni G, Vittori G and Larocca LM: Possible involvement of hMLH1, p16(INK4a) and PTEN in the malignant transformation of endometriosis. Int J Cancer 102: 398-406, 2002

38. Borghese B, Mondon F, Noël JC, Fayt I, Mignot TM, Vaiman D and Chapron C: Gene expression profile for ectopic versus eutopic endometrium provides new insights into endometriosis oncogenic potential. Mol Endocrinol 22: 2557-2562, 2008.

39. Kim JJ, Taylor HS, Lu Z, Ladhani O, Hastings JM, Jackson KS, Wu Y, Guo SW and Fazleabas AT: Altered expression of HOXA10 in endometriosis: Potential role in decidualization. Mol Hum Reprod 13: 323-332, 2007.

40. Zanatta A, Rocha AM, Carvalho FM, Pereira RM, Taylor HS, Motta EL, Baracat EC and Serafini PC: The role of the Hoxa10/HOXA10 gene in the etiology of endometriosis and its related infertility: A review. J Assist Reprod Genet 27: 701-710, 2010

41. Zhu Y, Luo M, Huang H, Du X, Chen D, Xing Q, Wang B and Cao Y: HOXA10, EMX2 and TENM1 expression in the midsecretory endometrium of infertile women with a Müllerian duct anomaly. Reprod Biomed Online 32: 388-393, 2016.

42. Wang M, Hao C, Huang X, Bao H, Qu Q, Liu Z, Dai H, He S and Yan W: Aberrant Expression of lncRNA ( HOXA11-AS1) and Homeobox A ( HOXA9, HOXA10, HOXA11, and HOXA13) Genes in Infertile Women With Endometriosis. Reprod Sci 25: 654-661, 2018.

43. Alizadeh Z, Shokrzadeh N, Saidijam M and Sanoee MF: Semiquantitative analysis of HOXA11, leukemia inhibitory factor and basic transcriptional element binding protein 1 mRNA expression in the mid-secretory endometrium of patients with endometriosis. Iran Biomed J 15: 66-72, 2011.

44. Camargo-Kosugi CM, da Silva IDCG, Sato H, D'Amora P, Carvalho CV, Nogueira-de-Souza NC, Girão MJ and Schor E: The V109G polymorphism in the p27 gene is associated with endometriosis. Eur J Obstet Gynecol Reprod Biol 145: 180-183, 2009.

45. Sahmani M, Darabi M, Darabi M, Dabaghi T, Alizadeh SA and Najafipour R: The $763 \mathrm{C}>\mathrm{G}$ Polymorphism of the secretory PLA2IIa gene is associated with endometriosis in Iranian women. Int J Fertil Steril 8: 437-444, 2015.

46. Christofolini DM, Mafra FA, Catto MC, Bianco B and Barbosa CP: New candidate genes associated to endometriosis. Gynecol Endocrinol 35: 62-65, 2019.

47. Ahn SH, Khalaj K, Young SL, Lessey BA, Koti M and Tayade C: Immune-inflammation gene signatures in endometriosis patients. Fertil Steril 106: 1420-1431.e7, 2016

48. Pissetti C, Tanaka S, Hortolani A and de Marqui A: Gene polymorphisms in FAS (Rs3740286 and Rs4064) areinvolved in endometriosis development in Brazilian women, but not those in CASP8 (rs13416436 and rs2037815). Rev Bras Ginecol Obstet 40: 450-457, 2018
49. Penna I, Du H, Ferriani R and Taylor HS: Calpain5 expression is decreased in endometriosis and regulated by HOXA10 in human endometrial cells. Mol Hum Reprod 14: 613-618, 2008.

50. Yoo JY,Kim TH, Fazleabas AT, Palomino WA, Ahn SH, Tayade C, Schammel DP, Young SL, Jeong JW and Lessey BA: KRAS Activation and over-expression of SIRT1/BCL6 Contributes to the Pathogenesis of Endometriosis and Progesterone Resistance. Sci Rep 7: 6765, 2017.

51. Kosugi Y, Elias S, Malinak LR, Nagata J, Isaka K, Takayama M, Simpson JL and Bischoff FZ: Increased heterogeneity of chromosome 17 aneuploidy in endometriosis. Am J Obstet Gynecol 180: 792-797, 1999.

52. Ying TH, Tseng CJ, Tsai SJ, Hsieh SC, Lee HZ, Hsieh YH and Bau DT: Association of p53 and CDKN1A genotypes with endometriosis. Anticancer Res 31: 4301-4306, 2011.

53. Li J, Chen Y, Mo Z and Li L: TP53 Arg72Pro polymorphism (rs1042522) and risk of endometriosis among Asian and Caucasian populations. Eur J Obstet Gynecol Reprod Biol 189: 73-78, 2015.

54. Chang CC, Hsieh YY, Tsai FJ, Tsai CH, Tsai HD and Lin CC: The proline form of $\mathrm{p} 53$ codon 72 polymorphism is associated with endometriosis. Fertil Steril 77: 43-45, 2002.

55. Jia S, Xu L, Chan Y, Wu X, Yang S, Yu H, Yang H, Luo Y and Tang W: p53 codon 72 polymorphism and endometriosis: A meta-analysis. Arch Gynecol Obstet 285: 1657-1661, 2012.

56. Tsuchiya M, Katoh T, Motoyama H, Sasaki H, Tsugane S and Ikenoue T: Analysis of the AhR, ARNT, and AhRR gene polymorphisms: Genetic contribution to endometriosis susceptibility and severity. Fertil Steril 84: 454-458, 2005.

57. Fan W, Huang Z, Xiao Z, Li S and Ma Q: The cytochrome P4501A1 gene polymorphisms and endometriosis: A metaanalysis. J Assist Reprod Genet 33: 1373-1383, 2016.

58. Gu C,Zhao LY, Huang K, Fan WS, Li LA and Ye MX: Association between CYP19 polymorphisms and endometriosis risk: A metaanalysis. Int J Clin Exp Med 9: 10706-10716, 2016.

59. Singh MN, Stringfellow HF, Taylor SE, Ashton KM, Ahmad M, Abdo KR, El-Agnaf OM, Martin-Hirsch PL and Martin FL: Elevated expression of CYP1A1 and $\gamma$-SYNUCLEIN in human ectopic (ovarian) endometriosis compared with eutopic endometrium. Mol Hum Reprod 14: 655-663, 2008.

60. Al-Rubae'i SH, Naji TS and Turki KM: Common variation of the CYP17 gene in Iraqi women with endometriosis disease. Genom Data 11: 55-59, 2016.

61. Huang PC, Li WF, Liao PC, Sun CW, Tsai EM and Wang SL: Risk for estrogen-dependent diseases in relation to phthalate exposure and polymorphisms of CYP17A1 and estrogen receptor genes. Environ Sci Pollut Res Int 21: 13964-13973, 2014.

62. Cong L, Fu Q and Gao T: CYP17A1 rs743572 polymorphism might contribute to endometriosis susceptibility: Evidences from a case-control study. Medicine (Baltimore) 97: e11415, 2018.

63. Juo SH, Wang TN, Lee JN, Wu MT, Long CY and Tsai EM: CYP17, CYP1A1 and COMT polymorphisms and the risk of adenomyosis and endometriosis in Taiwanese women. Hum Reprod 21: 1498-1502, 2006

64. Cayan F, Ayaz L, Aban M, Dilek S and Gümüş LT: Role of CYP2C19 polymorphisms in patients with endometriosis. Gynecol Endocrinol 25: 530-535, 2009.

65. Barcelos IDES, Donabella FC, Ribas CP, Meola J, Ferriani RA, de Paz CC and Navarro PA: Down-regulation of the CYP19A1 gene in cumulus cells of infertile women with endometriosis. Reprod Biomed Online 30: 532-541, 2015.

66. Vietri MT, Cioffi M, Sessa M, Simeone S, Bontempo P, Trabucco E, Ardovino M, Colacurci N, Molinari AM and Cobellis L: CYP17 and CYP19 gene polymorphisms in women affected with endometriosis. Fertil Steril 92: 1532-1535, 2009.

67. Wang L, Lu X, Wang D, Qu W, Li W, Xu X, Huang Q, Han X and Lv J: CYP19 gene variant confers susceptibility to endometriosisassociated infertility in Chinese women. Exp Mol Med 46: e103-e107, 2014.

68. Painter JN, Nyholt DR, Krause L, Zhao ZZ, Chapman B, Zhang C, Medland S, Martin NG, Kennedy S, Treloar S, et al: Common variants in the CYP2C19 gene are associated with susceptibility to endometriosis. Fertil Steril 102: 496-502.e5, 2014.

69. Cardoso JV, Machado DE, Ferrari R, Silva MCD, Berardo PT and Perini JA: Combined effect of the PGR +331C $>$ T, CYP17A1 -34A >G and CYP19A1 1531G > A polymorphisms on the risk of developing endometriosis. Rev Bras Ginecol Obstet 39: 273-281, 2017.

70. Kubiszeski EH, de Medeiros SF, da Silva Seidel JA, Barbosa JS, Galera MF and Galera BB: Glutathione S-transferase M1 and T1 gene polymorphisms in Brazilian women with endometriosis. J Assist Reprod Genet 32: 1531-1535, 2015. 
71. Fayez D, Saliminejad K, Irani S, Kamali K, Memariani T and Khorram Khorshid HR: Arylamine N-acetyltransferase 2 polymorphisms and the risk of endometriosis. Avicenna J Med Biotechnol 10: 163-167, 2018

72. Xin X, Jin Z, Gu H, Li Y, Wu T, Hua T and Wang H: Association between glutathione S-transferase M1/T1 gene polymorphisms and susceptibility to endometriosis: A systematic review and meta-analysis. Exp Ther Med 11: 1633-1646, 2016.

73. Zhu H, Bao J, Liu S, Chen Q and Shen H: Null genotypes of GSTM1 and GSTT1 and endometriosis risk: A meta-analysis of 25 case-control studies. PLoS One 9: e106761, 2014.

74. Tempfer CB, Simoni M, Destenaves B and Fauser BC: Functional genetic polymorphisms and female reproductive disorders: Part II--endometriosis. Hum Reprod Update 15: 97-118, 2009.

75. Hassani M, Saliminejad K, Heidarizadeh M, Kamali K, Memariani T and Khorram Khorshid HR: Association study of Glutathione S-Transferase polymorphisms and risk of endometriosis in an Iranian population. Int J Reprod Biomed (Yazd) 14: 241-246, 2016.

76. Arvanitis DA, Goumenou AG, Matalliotakis IM, Koumantakis EE and Spandidos DA: Low-penetrance genes are associated with increased susceptibility to endometriosis. Fertil Steril 76: 1202-1206, 2001

77. Arvanitis DA, Koumantakis GE, Goumenou AG, Matalliotakis IM, Koumantakis EE and Spandidos DA: CYP1A1, CYP19, and GSTM1 polymorphisms increase the risk of endometriosis. Fertil Steril 79 (Suppl 1): 702-709, 2003.

78. Sachan S, Nair R, Khanna A and Singh K: CYP1A1 and GSTM1 genes polymorphisms and its association with endometriosis: A pilot study. Asian Pac J Reprod 2: 297-300, 2103, 2013.

79. Seifati SM, Parivar K, Aflatoonian A, Dehghani Firouzabadi R and Sheikhha MH: No association of GSTM1 null polymorphism with endometriosis in women from central and southern Iran. Iran J Reprod Med 10: 23-28, 2012.

80. Docea AO, Vassilopoulou L, Fragou D, Arsene AL, Fenga C, Kovatsi L, Petrakis D, Rakitskii VN, Nosyrev AE, Izotov BN, et al: CYP polymorphisms and pathological conditions related to chronic exposure to organochlorine pesticides. Toxicol Rep 4: 335-341, 2017.

81. Vassilopoulou L, Psycharakis C, Petrakis D, Tsiaoussis J and Tsatsakis AM: Obesity, persistent organic pollutants and related health problems. Adv Exp Med Biol 960: 81-110, 2017.

82. Sofo V, Götte M, Laganà AS, Salmeri FM, Triolo O, Sturlese E, Retto G, Alfa M, Granese R and Abrão MS: Correlation between dioxin and endometriosis: An epigenetic route to unravel the pathogenesis of the disease. Arch Gynecol Obstet 292: 973-986, 2015.

83. Yao M, Hu T, Wang Y, Du Y, Hu C and Wu R: Polychlorinated biphenyls and its potential role in endometriosis. Environ Pollut 229: 837-845, 2017.

84. Marchand A, Tomkiewicz C, Marchandeau JP, Boitier E, Barouki R and Garlatti M: 2,3,7,8-Tetrachlorodibenzo-p-dioxin induces insulin-like growth factor binding protein-1 gene expression and counteracts the negative effect of insulin. Mol Pharmacol 67: 444-452, 2005.

85. Bruner-Tran KL, Resuehr D, Ding T, Lucas JA and Osteen KG: The role of endocrine disruptors in the epigenetics of reproductive disease and dysfunction: Potential relevance to humans. Curr Obstet Gynecol Rep 1: 116-123, 2012.

86. Bruner-Tran KL, Gnecco J, Ding T, Glore DR, Pensabene V and Osteen KG: Exposure to the environmental endocrine disruptor TCDD and human reproductive dysfunction: Translating lessons from murine models. Reprod Toxicol 68: 59-71, 2017.

87. Tsuchiya M, Tsukino H, Iwasaki M, Sasaki H, Tanaka T, Katoh T, Patterson DG Jr, Turner W, Needham L and Tsugane S: Interaction between cytochrome $\mathrm{P} 450$ gene polymorphisms and serum organochlorine TEQ levels in the risk of endometriosis. Mol Hum Reprod 13: 399-404, 2007.

88. Azimzadeh P, Khorram Khorshid HR, Akhondi MM and Shirazi A: Association of interleukin-16 polymorphisms with disease progression and susceptibility in endometriosis. Int J Immunogenet 43: 297-302, 2016

89. Matalliotakis M, Zervou MI, Eliopoulos E, Matalliotaki C, Rahmioglu N, Kalogiannidis I, Zondervan K, Spandidos DA, Matalliotakis I and Goulielmos GN: The role of IL 16 gene polymorphisms in endometriosis. Int J Mol Med 41: 1469-1476, 2018.

90. Zamani M and Javan M: Immunological Genetic Variants Underlying Endometriosis. SAJ Genet 1: 1-3, 2015.
91. Kitawaki J, Kiyomizu M, Obayashi H, Ohta M, Ishihara H, Hasegawa G, Nakamura N, Yoshikawa $\mathrm{T}$ and Honjo $\mathrm{H}$ : Synergistic effect of interleukin-6 promoter (IL6-634C/G) and intercellular adhesion molecule-1 (ICAM-1 469K/E) gene polymorphisms on the risk of endometriosis in Japanese women. Am J Reprod Immunol 56: 267-274, 2006

92. Bessa NZ, Francisco DO, Andres MP, Gueuvoghlanian-Silva BY, Podgaec S and Fridman C: Polymorphisms of ICAM-1 and IL-6 genes related to endometriosis in a sample of Brazilian women. J Assist Reprod Genet 33: 1487-1492, 2016.

93. Bhanoori M, Babu KA, Deenadayal M, Kennedy S and Shivaji S: The interleukin-6 $-174 \mathrm{G} / \mathrm{C}$ promoter polymorphism is not associated with endometriosis in South Indian women. J Soc Gynecol Investig 12: 365-369, 2005.

94. Yamashita M, Yoshida S, Kennedy S, Ohara N, Motoyama S and Maruo T: Association study of endometriosis and intercellular adhesion molecule-1 (ICAM-1) gene polymorphisms in a Japanese population. J Soc Gynecol Investig 12: 10-14, 2016.

95. Chishima F, Hayakawa S, Sugita K, Kinukawa N, Aleemuzzaman S, Nemoto N, Yamamoto T and Honda M: Increased expression of cyclooxygenase-2 in local lesions of endometriosis patients. Am J Reprod Immunol 48: 50-56, 2002.

96. Cavalcanti V, Ponce TG, Mafra FA, André GM, Christofolini DM, Barbosa CP and Bianco B: Evaluation of the frequency of G-765C polymorphism in the promoter region of the COX-2 gene and its correlation with the expression of this gene in the endometrium of women with endometriosis. Arch Gynecol Obstet 293: 109-115, 2016.

97. Kim HY, Cho S, Choi YS, Yang HI, Lee KE, Seo SK and Lee BS: Cyclooxygenase-2 (COX-2) gene-765G/C polymorphism and advanced-stage endometriosis in Korean women. Am J Reprod Immunol 68: 238-243, 2012.

98. D'Amora P, Sato H, Girão MJ, Silva ID and Schor E: Polymorphisms in exons 1B and 1C of the type I interleukin-1 receptor gene in patients with endometriosis. Am J Reprod Immunol 56: 178-184, 2006

99. Gajbhiye R, McKinnon B, Mortlock S, Mueller M and Montgomery G: Genetic variation at chromosome $2 \mathrm{q} 13$ and its potential influence on endometriosis susceptibility through effects on the IL-1 family. Reprod Sci 25: 1307-1317, 2018.

100. Hata Y, Nakaoka H, Yoshihara K, Adachi S, Haino K, Yamaguchi M, Nishikawa N, Kashima K, Yahata T, Tajima A, et al: A nonsynonymous variant of IL1A is associated with endometriosis in Japanese population. J Hum Genet 58: 517-520, 2013.

101. Hsieh YY, Chang CC, Tsai FJ, Wu JY, Shi YR, Tsai H-D and Tsai CH: Polymorphisms for interleukin-1 $\beta$ (IL-1 $\beta$ )-511 promoter, IL-1 $\beta$ exon 5 , and IL-1 receptor antagonist: Nonassociation with endometriosis. J Assist Reprod Genet 18: 506-511, 2001

102. Attar R, Agachan B, Kucukhuseyin O, Toptas B, Attar E and Isbir T: Association of interleukin lbeta gene (+3953) polymorphism and severity of endometriosis in Turkish women. Mol Biol Rep 37: 369-374, 2010.

103. Sapkota Y, Low SK, Attia J, Gordon SD, Henders AK, Holliday EG, MacGregor S, Martin NG, McEvoy M, Morris AP, et al: Association between endometriosis and the interleukin $1 \mathrm{~A}$ (IL1A) locus. Hum Reprod 30: 239-248, 2015.

104. Hsieh YY, Chang CC, Tsai FJ, Hsu CM, Lin CC and Tsai CH: Interleukin-2 receptor $\beta$ (IL-2R $\beta$ )- $627 * \mathrm{C}$ homozygote but not IL-12R $\beta 1$ codon 378 or IL-18 105 polymorphism is associated with higher susceptibility to endometriosis. Fertil Steril 84: 510-512, 2005.

105.Lee GH, Choi YM, Kim SH, Hong MA, Ku SY, Kim SH, Kim JG and Moon SY: Interleukin-2 receptor $\beta$ gene C627T polymorphism in Korean women with endometriosis: A casecontrol study. Hum Reprod 24: 2596-2599, 2009.

106. Riiskjaer M, Nielsen K, Steffensen R, Erikstrup C, Forman A and Kruse C: Association of interleukin - 10 promoter polymorphism and endometriosis. Am J Reprod Immunol 65: 13-19, 2011.

107. Juo S-HH, Wu R, Lin C-S, Wu M-T, Lee JN and Tsai EM: A functional promoter polymorphism in interleukin-10 gene influences susceptibility to endometriosis. Fertil Steril 92: 1228-1233, 2009.

108. Malutan AM, Drugan C, Drugan T, Ciortea R and Mihu D: The association between interleukin-4 -590C/T genetic polymorphism, IL-4 serum level, and advanced endometriosis. Cent Eur J Immunol 41: 176-181, 2016. 
109.Zhao W, Li Y, Zhao J and Kang S: A functional promoter polymorphism in interleukin $12 \mathrm{~B}$ gene is associated with an increased risk of ovarian endometriosis. Gene 666: 27-31, 2018.

110. Borghese B, Chiche JD, Vernerey D, Chenot C, Mir O, Bijaoui G, Bonaiti-Pellié $\mathrm{C}$ and Chapron C: Genetic polymorphisms of matrix metalloproteinase 12 and 13 genes are implicated in endometriosis progression. Hum Reprod 23: 1207-1213, 2008.

111. Ueda M, Yamashita Y, Takehara M, Terai Y, Kumagai K, Ueki K, Kanda K, Yamaguchi H, Akise D, Hung YC, et al: Survivin gene expression in endometriosis. J Clin Endocrinol Metab 87: 3452-3459, 2002.

112. Borghese B, Gayet V, Chiche JD, Vernerey D, de Ziegler D, Bonaiti-Pellié $\mathrm{C}$ and Chapron C: Absence of association between a functional polymorphism of ALOX15 gene and infertility in endometriosis. Fertil Steril 91 (Suppl 4): 1414-1416, 2009.

113. Nowak I, Płoski R, Barcz E, Dziunycz P, Kamiński P, Kostrzewa G, Milewski Ł, Roszkowski PI, Senitzer D, Malejczyk J, et al: KIR2DS5 in the presence of HLA-C C2 protects against endometriosis. Immunogenetics 67: 203-209, 2015.

114. Bylińska A, Wilczyńska K, Malejczyk J, Milewski Ł, Wagner M, Jasek M, Niepiekło-Miniewska W, Wiśniewski A, Płoski R, Barcz E, et al: The impact of HLA-G, LILRB1 and LILRB2 gene polymorphisms on susceptibility to and severity of endometriosis. Mol Genet Genomics 293: 601-613, 2018.

115. Chang CY, Chen Y, Lin WC, Chen CM, Chen CP, Lee SC, Sheu JJ and Tsai FJ: MUC2 polymorphisms are associated with endometriosis development and infertility: A case-control study. BMC Med Genet 13: 15, 2012

116. Chang CY, Chang HW, Chen CM, Lin CY, Chen C-P, Lai CH, Lin WY, Liu HP, Sheu JJ and Tsai FJ: MUC4 gene polymorphisms associate with endometriosis development and endometriosis-related infertility. BMC Med 9: 19, 2011.

117. Lee GH, Choi YM, Kim SH, Hong MA, Oh ST, Lim YT and Moon SY: Association of tumor necrosis factor-\{alpha\} gene polymorphisms with advanced stage endometriosis. Hum Reprod 23: 977-981, 2008.

118. Peluso C, Christofolini DM, Goldman CS, Mafra FA, Cavalcanti V, Barbosa CP and Bianco B: TYK2 rs34536443 polymorphism is associated with a decreased susceptibility to endometriosis-related infertility. Hum Immunol 74: 93-97, 2013.

119. Ammendola M, Pietropolli A, Saccucci P, Piccione E, Bottini E and Gloria-Bottini F: Acid phosphatase locus 1 genetic polymorphism, endometriosis, and allergy. Fertil Steril 90: 1203-1205, 2008.

120. Gomes FM, Bianco B, Teles JS, Christofolini DM, de Souza AM, Guedes AD and Barbosa CP: PTPN22 C1858T polymorphism in women with endometriosis. Am J Reprod Immunol 63: 227-232, 2010.

121.Płoski R, Dziunycz P, Kostrzewa G, Roszkowski PI, Barcz E, Zabek J, Milewski Ł, Kamiński P and Malejczyk J: PTPN22/ LYP $1858 \mathrm{C}>\mathrm{T}$ gene polymorphism and susceptibility to endometriosis in a Polish population. J Reprod Immunol 79: 196-200, 2009.

122. Gloria-Bottini F, Ammendola M, Saccucci P, Pietropolli A, Magrini A and Bottini E: The association of PTPN22 polymorphism with endometriosis: Effect of genetic and clinical factors. Eur J Obstet Gynecol Reprod Biol 169: 60-63, 2013.

123.Zhang H, Zhang Z, Li G, Wang S, Zhang S and Xie B: Association of FCRL3 Genetic Polymorphisms With Endomeriosis-Related Infertility Risk. Medicine (Baltimore) 94: 1-8, 2015.

124.Zou Y, Zhou JY, Wang F, Zhang ZY, Liu FY, Luo Y, Tan J, Zeng X, Wan XD and Huang OP: Analysis of CARD10 and CARD11 somatic mutations in patients with ovarian endometriosis. Oncol Lett 16: 491-496, 2018.

125.Kang S, Li SZ, Wang N, Zhou RM, Wang T, Wang DJ, Li XF, Bui J and Li Y: Association between genetic polymorphisms in fibroblast growth factor (FGF)1 and FGF2 and risk of endometriosis and adenomyosis in Chinese women. Hum Reprod 25: 1806-1811, 2010.

126.Zhao ZZ, Pollock PM, Thomas S, Treloar SA, Nyholt DR and Montgomery GW: Common variation in the fibroblast growth factor receptor 2 gene is not associated with endometriosis risk. Hum Reprod 23: 1661-1668, 2008.

127. Kim SH, Choi YM, Choung SH, Jun JK, Kim JG and Moon SY: Vascular endothelial growth factor gene $+405 \mathrm{C} / \mathrm{G}$ polymorphism is associated with susceptibility to advanced stage endometriosis. Hum Reprod 20: 2904-2908, 2005.
128. Fang F, Gong L, Wang $X$ and Zhang L: The association between vascular endothelial growth factor (VEGF) $+405 \mathrm{G}>\mathrm{C}$ genetic polymorphism and endometriosis. Exp Biol Med (Maywood) 240: 1177-1182, 2015.

129. Lamp M, Saare M, Laisk T, Karro H, Kadastik U, Metspalu A, Peters $M$ and Salumets A: Genetic variations in vascular endothelial growth factor but not in angiotensin I-converting enzyme genes are associated with endometriosis in Estonian women. Eur J Obstet Gynecol Reprod Biol 153: 85-89, 2010.

130. Li YZ, Wang LJ, Li X, Li SL, Wang JL, Wu ZH, Gong L and Zhang XD: Vascular endothelial growth factor gene polymorphisms contribute to the risk of endometriosis: An updated systematic review and meta-analysis of 14 case-control studies. Genet Mol Res 12: 1035-1044, 2013.

131. Liang S, Huang Y and Fan Y: Vascular endothelial growth factor gene polymorphisms and endometriosis risk: A meta-analysis. Arch Gynecol Obstet 286: 139-146, 2012.

132. Liu Q, Li Y, Zhao J, Sun DL, Duan YN, Wang N, Zhou RM and Kang S: Association of polymorphisms $-1154 \mathrm{G} / \mathrm{A}$ and $-2578 \mathrm{C} / \mathrm{A}$ in the vascular endothelial growth factor gene with decreased risk of endometriosis in Chinese women. Hum Reprod 24: 2660-2666, 2009.

133. Perini JA, Cardoso JV, Berardo PT, Vianna-Jorge R, Nasciutti LE, Bellodi-Privato M, Machado DE and Abrão MS: Role of vascular endothelial growth factor polymorphisms $(-2578 \mathrm{C}>\mathrm{A},-460 \mathrm{~T}>\mathrm{C},-1154 \mathrm{G}>\mathrm{A},+405 \mathrm{G}>\mathrm{C}$ and $+936 \mathrm{C}>\mathrm{T})$ in endometriosis: A case-control study with Brazilians. BMC Womens Health 14: 117, 2014.

134. Szczepańska M, Mostowska A, Wirstlein P, Skrzypczak J and Jagodziłski PP: Involvement of vascular endothelial growth factor $-460 \mathrm{C} / \mathrm{T},+405 \mathrm{G} / \mathrm{C}$ and $+936 \mathrm{C} / \mathrm{T}$ polymorphisms in the development of endometriosis. Biomed Rep 3: 220-224, 2015.

135. Xu S, Wu W, Sun H, Lu J, Yuan B, Xia Y, De Moor B, Marchal K, Wang X, Xu P, et al: Association of the vascular endothelial growth factor gene polymorphisms $(-460 \mathrm{C} / \mathrm{T},+405 \mathrm{G} / \mathrm{C}$ and +936T/C) with endometriosis: A meta-analysis. Ann Hum Genet 76: 464-471, 2012.

136. Vodolazkaia A, Yesilyurt BT, Kyama CM, Bokor A, Schols D, Huskens D, Meuleman C, Peeraer K, Tomassetti C, Bossuyt X, et al: Vascular endothelial growth factor pathway in endometriosis: Genetic variants and plasma biomarkers. Fertil Steril 105: 988-996, 2016.

137. Laudanski P, Charkiewicz R, Kuzmicki M, Szamatowicz J, Świątecka J, Mroczko B and Niklinski J: Profiling of selected angiogenesis-related genes in proliferative eutopic endometrium of women with endometriosis. Eur J Obstet Gynecol Reprod Biol 172: 85-92, 2014.

138. Araujo FM, Meola J, Rosa-E-Silva JC, Paz CCP, Ferriani RA and Nogueira AA: Increased expression of ID2, PRELP and SMOC2 genes in patients with endometriosis. Braz J Med Biol Res 50: e5782, 2017.

139. Yeo SG, Won YS, Lee HY, Kim YI, Lee JW and Park DC: Increased expression of pattern recognition receptors and nitric oxide synthase in patients with endometriosis. Int J Med Sci 10: 1199-1208, 2013.

140. Kim H, Ku SY, Kim SH, Lee GH, Choi YM, Kim JM, Lee TH and Moon SY: Endothelial nitric oxide synthase gene Glu298Asp polymorphism is associated with advanced stage endometriosis. Hum Reprod 24: 2656-2659, 2009.

141. Bhanoori M, Kameshwari DB, Zondervan KT, Deenadayal M, Kennedy S and Shivaji S: The endothelial nitric oxide synthase Glu298Asp polymorphism is not a risk factor for endometriosis in south Indian women. Eur J Obstet Gynecol Reprod Biol 139: $53-58,2008$.

142. André GM, Martins Trevisan C, Pedruzzi IN, Fernandes RF Oliveira R, Christofolini DM, Bianco B, Barbosa CP and Barbosa CP: The Impact of FSHR Gene Polymorphisms Ala307Thr and Asn680Ser in the Endometriosis Development. DNA Cell Biol 37: 584-591, 2018.

143. Schmitz CR, Souza CA, Genro VK, Matte U, Conto E and Cunha-Filho JS: LH (Trp8Arg/Ile15Thr), LHR (insLQ) and FSHR (Asn680Ser) polymorphisms genotypic prevalence in women with endometriosis and infertility. J Assist Reprod Genet 32: 991-997, 2015.

144. De Conto E, Matte Ú, Bilibio JP, Genro VK, Souza CA, Leão DP and Cunha-Filho JS: Endometriosis-associated infertility: GDF-9, AMH, and AMHR2 genes polymorphisms. J Assist Reprod Genet 34: 1667-1672, 2017. 
145. Gentilini D, Vigano P, Carmignani L, Spinelli M, Busacca M and Di Blasio AM: Progesterone receptor $+331 \mathrm{G} / \mathrm{A}$ polymorphism in endometriosis and deep-infiltrating endometriosis. Fertil Steril 90: 1243-1245, 2008.

146. Lee RC, Feinbaum RL and Ambros V: The C. elegans heterochronic gene lin-4 encodes small RNAs with antisense complementarity to lin-14. Cell 75: 843-854, 1993.

147. Agrawal S, Tapmeier T, Rahmioglu N, Kirtley S, Zondervan K and Becker C: The miRNA mirage: How close are we to finding a non-invasive diagnostic biomarker in endometriosis? a systematic review. Int J Mol Sci 19: E599, 2018.

148.Eggers JC, Martino V, Reinbold R, Schäfer SD, Kiesel L, Starzinski-Powitz A, Schüring AN, Kemper B, Greve B and Götte M: microRNA miR-200b affects proliferation, invasiveness and stemness of endometriotic cells by targeting ZEB1, ZEB2 and KLF4. Reprod Biomed Online 32: 434-445, 2016.

149.Zhou M, Fu J, Xiao L, Yang S, Song Y, Zhang X, Feng X, Sun H, Xu W and Huang W: miR-196a overexpression activates the MEK/ERK signal and represses the progesterone receptor and decidualization in eutopic endometrium from women with endometriosis. Hum Reprod 31: 2598-2608, 2016.

150. Sahin C, Mamillapalli R, Yi KW and Taylor HS: microRNA Let-7b: A Novel treatment for endometriosis. J Cell Mol Med 22: 5346-5353, 2018.

151. Kitawaki J, Kado N, Ishihara H, Koshiba H, Kitaoka Y and Honjo H: Endometriosis: The pathophysiology as an estrogendependent disease. J Steroid Biochem Mol Biol 83: 149-155, 2002

152. Matsuzaka Y, Kikuti YY, Izumi S, Goya K, Suzuki T, Cai LY, Oka A, Inoko H, Kulski JK and Kimura M: Failure to detect significant association between estrogen receptor-alpha gene polymorphisms and endometriosis in Japanese women. Environ Health Prev Med 17: 423-428, 2012.

153. Paskulin DD, Cunha-Filho JS, Paskulin LD, Souza CA and Ashton-Prolla P: ESR1 rs9340799 is associated with endometriosis-related infertility and in vitro fertilization failure. Dis Markers 35: 907-913, 2013.

154. Wang Z, Yoshida S, Negoro K, Kennedy S, Barlow D and Maruo T: Polymorphisms in the estrogen receptor $\beta$ gene but not estrogen receptor $\alpha$ gene affect the risk of developing endometriosis in a Japanese population. Fertil Steril 81: 1650-1656, 2004.

155. Zhao L, Gu C, Huang K, Fan W, Li L, Ye M, Han W and Meng Y: Association between oestrogen receptor alpha (ESR1) gene polymorphisms and endometriosis: A meta-analysis of 24 case-control studies. Reprod Biomed Online 33: 335-349, 2016.

156. Mathew D, Drury JA, Valentijn AJ, Vasieva O and Hapangama DK: In silico, in vitro and in vivo analysis identifies a potential role for steroid hormone regulation of FOXD3 in endometriosis-associated genes. Hum Reprod 31: 345-354, 2016.

157. Osiński M,MostowskaA,WirstleinP,SkrzypczakJ,JagodzińskiPP and Szczepańska M: Involvement of 17 $\beta$-hydroxysteroid dehydrogenase type gene $1937 \mathrm{~A}>\mathrm{G}$ polymorphism in infertility in Polish Caucasian women with endometriosis. J Assist Reprod Genet 34: 789-794, 2017.

158. Casals G, Ordi J, Creus M, Fábregues F, Carmona F, Casamitjana R and Balasch J: Expression pattern of osteopontin and $\alpha v \beta 3$ integrin during the implantation window in infertile patients with early stages of endometriosis. Hum Reprod 27: 805-813, 2012.

159. Focarelli R, Luddi A, De Leo V, Capaldo A, Stendardi A, Pavone V, Benincasa L, Belmonte G, Petraglia F and Piomboni P: Dysregulation of GdA Expression in Endometrium of Women With Endometriosis: Implication for Endometrial Receptivity. Reprod Sci 25: 579-586, 2018.

160. Goumenou AG, Matalliotakis IM, Tzardi M, Fragouli IG Mahutte NG and Arici A: p16, retinoblastoma (pRb), and cyclin D1 protein expression in human endometriotic and adenomyotic lesions. Fertil Steril 85 (Suppl 1): 1204-1207, 2006.

161. Bush WS and Moore JH: Chapter 11: Genome-wide association studies. PLOS Comput Biol 8: e1002822, 2012.

162. Adachi S, Tajima A, Quan J, Haino K, Yoshihara K, Masuzaki H, Katabuchi H, Ikuma K, Suginami H, Nishida N, et al: Meta-analysis of genome-wide association scans for genetic susceptibility to endometriosis in Japanese population. J Hum Genet 55: 816-821, 2010 .
163. Albertsen HM, Chettier R, Farrington $\mathrm{P}$ and Ward $\mathrm{K}$ : Genome-wide association study link novel loci to endometriosis PLoS One 8: e58257, 2013.

164. Borghese B, Tost J, De Surville M, Busato F, Letourneur F, Mondon F, Vaiman D and Chapron C: Identification of susceptibility genes for peritoneal, ovarian, and deep infiltrating endometriosis using a pooled sample-based genome-wide association study. Biomed Res Int 2015: 461024, 2015

165. Nakaoka H, Gurumurthy A, Hayano T, Ahmadloo S, Omer WH, Yoshihara K, Yamamoto A, Kurose K, Enomoto T, Akira S, et al: Allelic imbalance in regulation of ANRIL through chromatin interaction at 9p21 endometriosis risk locus. PLoS Genet 12: e1005893, 2016

166. Nyholt DR, Low S-K, Anderson CA, Painter JN, Uno S, Morris AP, MacGregor S, Gordon SD, Henders AK, Martin NG, et al: Genome-wide association meta-analysis identifies new endometriosis risk loci. Nat Genet 44: 1355-1359, 2012.

167. Pagliardini L, Gentilini D, Vigano' P, Panina-Bordignon P, Busacca M, Candiani M and Di Blasio AM: An Italian association study and meta-analysis with previous GWAS confirm WNT4, CDKN2BAS and FN1 as the first identified susceptibility loci for endometriosis. J Med Genet 50: 43-46, 2013.

168. Painter JN, Anderson CA, Nyholt DR, Macgregor S, Lin J, Lee SH, Lambert A, Zhao ZZ, Roseman F, Guo Q, et al: Genome-wide association study identifies a locus at $7 \mathrm{p} 15.2$ associated with endometriosis. Nat Genet 43: 51-54, 2011.

169. Uno S, Zembutsu H, Hirasawa A, Takahashi A, Kubo M, Akahane T, Aoki D, Kamatani N, Hirata K and Nakamura Y: A genome-wide association study identifies genetic variants in the CDKN2BAS locus associated with endometriosis in Japanese. Nat Genet 42: 707-710, 2010

170. Painter JN, O'Mara TA, Morris AP, Cheng THT, Gorman M, Martin L, Hodson S, Jones A, Martin NG, Gordon S, et al: Genetic overlap between endometriosis and endometrial cancer: Evidence from cross-disease genetic correlation and GWAS meta-analyses. Cancer Med 7: 1978-1987, 2018.

171. Rahmioglu N, MacGregor S, Drong A, Hedman A, Harris H, Randall J and Prokopenko I: International Endogene Consortium (IEC), The GIANT Consortium: Genome-wide enrichment analysis between endometriosis and obesity-related traits reveals novel susceptibility loci. Hum Mol Genet 2014: 1-15, 2014.

172. Sapkota Y, Fassbender A, Bowdler L, Fung JN, Peterse D, O D, Montgomery GW, Nyholt DR and D'Hooghe TM: Independent replication and meta-analysis for endometriosis risk loci. Twin Res Hum Genet 18: 518-525, 2015.

173. Steinthorsdottir V, Thorleifsson G, Aradottir K, Feenstra B, Sigurdsson A, Stefansdottir L, Kristinsdottir AM, Zink F, Halldorsson GH, Munk Nielsen N, et al: Common variants upstream of KDR encoding VEGFR 2 and in TTC39B associate with endometriosis. Nat Commun 7: 12350, 2016.

174. Uimari O, Rahmioglu N, Nyholt DR, Vincent K, Missmer SA Becker C, Morris AP, Montgomery GW and Zondervan KT: Genome-wide genetic analyses highlight mitogen-activated protein kinase (MAPK) signaling in the pathogenesis of endometriosis. Hum Reprod 32: 780-793, 2017.

175. Hirschhorn JN and Altshuler D: Once and again-issues surrounding replication in genetic association studies. J Clin Endocrinol Metab 87: 4438-4441, 2002.

176. Dun EC, Taylor RN and Wieser F: Advances in the genetics of endometriosis. Genome Med 2: 75, 2010.

177. Ng SB, Turner EH, Robertson PD, Flygare SD, Bigham AW, Lee C, Shaffer T, Wong M, Bhattacharjee A, Eichler EE, et al: Targeted capture and massively parallel sequencing of 12 human exomes. Nature 461: 272-276, 2009.

178. Fung JN, Rogers PAW and Montgomery GW: Identifying the biological basis of GWAS hits for endometriosis. Biol Reprod 92: 87, 2015.

This work is licensed under a Creative Commons Attribution-NonCommercial-NoDerivatives 4.0 International (CC BY-NC-ND 4.0) License. 